\title{
Exploring the classification of cancer cell lines from multiple omic views
}

\author{
Xiaoxi Yang ${ }^{1}$, Yuqi Wen ${ }^{1}$, Xinyu Song $^{2}$, Song He ${ }^{\text {Corresp., } 1}{ }^{1}$ Xiaochen Bo ${ }^{\text {Corresp. } 1}$ \\ ${ }^{1}$ Department of Biotechnology, Beijing Institute of Radiation Medicine, Beijing, China \\ Beijing, China \\ Corresponding Authors: Song He, Xiaochen Bo \\ Email address: hes1224@163.com, boxc@bmi.ac.cn
}

Background. Cancer classification is of great importance to understanding its pathogenesis, making diagnosis and developing treatment. The accumulation of extensive omics data of abundant cancer cell line provide basis for large scale classification of cancer with low cost. However, the reliability of cell lines as in vitro models of cancer has been controversial.

Methods. In this study, we explore the classification on pan-cancer cell line with single and integrated multiple omics data from the Cancer Cell Line Encyclopedia (CCLE) database. The representative omics data of cancer, mRNA data, miRNA data, copy number variation data, DNA methylation data and reversephase protein array data were taken into the analysis. TumorMap web tool was used to illustrate the landscape of molecular classification. The molecular classification of patient samples was compared with cancer cell lines.

Results. Eighteen molecular clusters were identified using integrated multiple omics clustering. Three pan-cancer clusters were found in integrated multiple omics clustering. By comparing with single omics clustering, we found that integrated clustering could capture both shared and complementary information from each omics data. Omics contribution analysis for clustering indicated that, although all the five omics data were of value, mRNA and proteomics data were particular important. While the classifications were generally consistent, samples from cancer patients were more diverse than cancer cell lines.

Conclusions. The clustering analysis based on integrated omics data provides a novel multi-dimensional map of cancer cell lines that can reflect the extent to pan-cancer cell lines represent primary tumors, and an approach to evaluate the importance of omic features in cancer classification. 
1 Exploring the classification of cancer cell lines from multiple omic views

2

3 Xiaoxi Yang ${ }^{1}$, Yuqi Wen ${ }^{1}$, Xinyu Song ${ }^{2}$, Song $\mathrm{He}^{1}$ and Xiaochen Bo ${ }^{1}$

4

$5{ }^{1}$ Department of Biotechnology, Beijing Institute of Radiation Medicine, Beijing, China.

$6{ }^{2}$ Key Laboratory of Biomedical Engineering and Translational Medicine, Ministry of Industry

7 and Information Technology, Chinese PLA General Hospital, Beijing, China.

8

9 Corresponding Author:

10 Xiaochen Bo ${ }^{1}$ and Song $\mathrm{He}^{1}$

11 Taiping Road, Beijing, 100850, China.

12 E-mail address: boxc@bmi.ac.cn, hes1224@163.com 


\section{Abstract}

15 Background. Cancer classification is of great importance to understanding its pathogenesis, 16 making diagnosis and developing treatment. The accumulation of extensive omics data of 17 abundant cancer cell line provide basis for large scale classification of cancer with low cost. 18 However, the reliability of cell lines as in vitro models of cancer has been controversial.

19 Methods. In this study, we explore the classification on pan-cancer cell line with single and 20 integrated multiple omics data from the Cancer Cell Line Encyclopedia (CCLE) database. The 21 representative omics data of cancer, mRNA data, miRNA data, copy number variation data, 22 DNA methylation data and reverse-phase protein array data were taken into the analysis. 23 TumorMap web tool was used to illustrate the landscape of molecular classification. The 24 molecular classification of patient samples was compared with cancer cell lines.

25 Results. Eighteen molecular clusters were identified using integrated multiple omics clustering.

26 Three pan-cancer clusters were found in integrated multiple omics clustering. By comparing with 27 single omics clustering, we found that integrated clustering could capture both shared and 28 complementary information from each omics data. Omics contribution analysis for clustering 29 indicated that, although all the five omics data were of value, mRNA and proteomics data were 30 particular important. While the classifications were generally consistent, samples from cancer 31 patients were more diverse than cancer cell lines.

32 Conclusions. The clustering analysis based on integrated omics data provides a novel multi33 dimensional map of cancer cell lines that can reflect the extent to pan-cancer cell lines represent 34 primary tumors, and an approach to evaluate the importance of omic features in cancer 35 classification. 


\section{Introduction}

38 Disease classification provides key foundations for identification and treatment of diseases,

39 especially for complicated diseases such as cancer (Song et al., 2015a). Traditional classification

40 of cancer was based on diseased organ, shared clinical symptoms and histological type

41 (Dozmorov, 2018; Ogino et al., 2012; Song et al., 2015a). In recent years, the rapid development

42 of high-throughput omics techniques and the accumulation of omics data enhances deeper

43 understanding of cancer classification and characterization in oncology research (Song et al.,

$442015 a$ ). Molecular classification based on omics data is now becoming important evidence for

45 individual treatment of several cancer subtypes (Koboldt et al., 2012; Tan et al., 2019). Several

46 studies have systematically characterized molecular classification of multiple cancer types based

47 on The Cancer Genome Atlas (TCGA) and other projects (Heim et al., 2014; International

48 Cancer Genome et al., 2010). As early as 2014, Hoadley et al. reported an integrated analysis of

4912 different cancers across six platforms, and redefined cancer types based on molecular

50 characteristics (Hoadley et al., 2014). In 2018, the group further identified 28 distinct molecular

51 pan-cancer subtypes arising from 33 cancers by integrating four types of omics data, providing a

52 supplementing classification system to anatomic taxonomy (Hoadley et al., 2018).

53 Due to the difficulties to collect clinical samples from cancer patients, cancer cell lines had

54 been still widely used as in vitro model for exploring cancer occurrence, development, and

55 treatments. In some cancer types, the classification analysis of cancer cell lines has been proved

56 to be a convenient way to characterize cancer sample subtypes. For example, five subtypes of

57 colorectal cancer were revealed by iterative clustering of 74 different colorectal cancer cell lines,

58 reflecting the consistency with the clinical classification of colorectal cancer patients (Schlicker

59 et al., 2012). On the other hand, however, the reliability of cell lines as in vitro models of cancer

60 samples has been doubted repeatedly. Previous studies have shown that in some cancer types,

61 existing cell lines do not fully represent all tumor subtypes. For example, Domcke et al.

62 compared the similarities and differences between the high-grade serous ovarian carcinomas cell

63 lines and the primary tumors that they represent. They found that the most representative ovarian 
64 carcinomas cell lines were rarely studied as in vitro models, while other ovarian cancer cell lines

65

66

67

68

69

70

71

72

73

74

75

76

77

78

79

80

81

82

83

84

85

86

87

88

89

90 were commonly used (Domcke et al., 2013). In addition, there is still lack of a comprehensive and complete profiling of pan-cancer cell lines classification based on integrated multiple omics data. Recently, Li et al. used reverse phase protein arrays data to divide about 650 cell lines into 10 pan-cancer groups which contributed a molecular portrait of cancer cell lines based on proteomics ( $\mathrm{Li}$ et al., 2017). Although great progresses have been made in the classification of pan-cancer samples based on integrated multiple omics data, there has been no research for providing an integrated molecular view of cancer cell lines based on multiple omics data and few publications have attempted to compare the classification of pan-cancer cell lines and patient samples.

In this study, we presented a systematic study on pan-cancer cell line classification based on single and integrated multiple omics data from the Cancer Cell Line Encyclopedia (CCLE) database (Ghandi et al., 2019). Our study seeks to provide a molecular classification to show a novel multi-dimensional map of pan-cancer cell lines and to compare the classification results obtained from our analysis with those of patient samples. The pan-cancer cell lines from CCLE were clustered in terms of single and multiple omics data using mRNA sequence data (mRNA), miRNA expression data (miRNA), copy number variation data (CNV), DNA methylation data (METHY) and reverse-phase protein array data (RPPA). Distinct molecular groups were identified by integrating five omics data. By characterizing each group by functional and cell-oforigin enrichment analysis, we confirmed significant molecular heterogeneity even among different cell lines of the same cancer type. Several pan-organ system clusters and a pansquamous morphology carcinoma cluster were also found among these molecular groups. By comparing with single omics clustering, we found that integrated multiple omics clustering could significantly capture more information of omics data. Additionally, we quantified the contribution analysis of each omics data for integrated clustering. The comparison of patient samples and cell lines classification results reveals that the classification of patient samples are more diverse and abundant than cancer cell lines. 
92 Materials \& Methods

\section{Cancer cell lines and data pre-processing}

94 Our study involved 1,019 cell lines from 31 previously established cancer types. The mRNA, 95 miRNA, CNV, METHY and RPPA data were downloaded from the CCLE database for all cell lines (https://portals.broadinstitute.org/ccle/data) (Ghandi et al., 2019). The number of cancer

97

98 cell lines and the cancer types involved were shown in Table 1.

For mRNA sequence data, we used RSEM values in gene level shared by CCLE database. We used miRNA expression data from CCLE for miRNA analysis. For DNA methylation, the promoter $\mathrm{CpG}$ data was used for clustering analysis. And reverse phase protein array data was downloaded for protein analysis. In parallel, we downloaded segmented copy number profiles from CCLE database for CNV analysis. This SNP6.0 arrays data was used as the input data for Gistic2.0 software (Mermel et al., 2011). Before pre-processing the data, we mapped segmented copy number to the chromosome arm level using Gistic2.0. This copy number variation by the chromosome arm level was the input data of CNV clustering analysis. Next, the following steps were performed to improve the dataset quality for single omics clustering.

(1) For each omics dataset, cell lines with more than $20 \%$ features missing, and features with more than $20 \%$ cell lines missing were filtered out.

(2) For each omics dataset, the missing data points were filled in using average imputations.

(3) For mRNA and miRNA data, $\log 2(x+1)$ ( $x$ is the value of mRNA and miRNA) transformation were performed before feature selection.

(4) For mRNA and METHY data, only features in the top 5,000 in terms of variance were selected. For miRNA, RPPA and CNV data, all features were considered.

For integrated multiple omics clustering, 670 cell lines from 24 cancer types with complete five omics data were used after samples alignment and deletion of cancer types with few number of cell lines. 
118 For single omics dataset, we performed hierarchical clustering with different methods and 119 distance measurements (Table 2). We used 30 clustering validity indices to select the optimal 120 clustering number using the R package "NbClust" (version 3.0) (Charrad et al., 2014). The 121 optimal parameters for function "NbClust" were set as follows: $\min . \mathrm{nc}=10$, $\max . \mathrm{nc}=30$, 122 method = "average".

123 The Similarity Network Fusion and Consensus clustering algorithm (SNF-CC), a method 124 combining Similarity Network Fusion (SNF) and Consensus clustering (CC) together to take 125 advantage of both for cancer type identification, was applied to integrate multiple omics data 126 (Monti et al., 2003; Wang et al., 2014). The method was implemented by the R package 127 “CancerSubtypes” (version 1.8.0) (Xu et al., 2017). The optimal parameters for function

128 "ExecuteSNF.CC" from "CancerSubtypes" were set as follows: $\mathrm{K}=20$, alpha $=0.5, \mathrm{t}=20$, $129 \operatorname{maxK}=30, \mathrm{pItem}=0.8$, reps $=500$. The silhouette coefficient, a measurement of consistency of 130 each object within clusters, also derived using the function "silhouette_SimilarityMatrix" from 131 the R package "CancerSubtypes".

132 The function "pamr.listgenes" from the "pamr" R package (version 1.56.1) was used to find 133 the most suitable clustering features for the illustration of clustering by heatmap (Tibshirani et 134 al., 2002).

\section{Dominant cancer type and functional enrichment analysis}

136 A hypergeometric distribution was used to calculate the P-value for cancer types in each cluster.

137 Cancer types with a $\mathrm{P}$-value $<10^{-3}$ were chosen as the dominant types of each cluster. $\mathrm{The}-\lg (\mathrm{P}-$ 138 value) represents the enrichment score that cancer types gathered in each cluster.

139 We explored the differential expressed genes (DEGs) among clusters using the R package

140 "limma" (version 3.38.3) (Ritchie et al., 2015). Genes with adjusted P-value $<0.05$ were

141 selected, and were further screened according to $\mid \log 2$ fold-change $\mid>1$. Finally, the above DEGs

142 were fed into enrichment analysis with GO and KEGG terms using the R package

143 "clusterProfiler" (version 3.10.1) (Yu et al., 2012). The significantly enriched pathways were 144 identified using false discovery rate $<0.05$. 


\section{Feature contribution of integrated multiple omics clustering}

146 We used the Normalized mutual information (NMI), which was a measure of the

147 interdependence between two random variables, to measure the contribution of each omics type

148 feature. The function "rankFeaturesByNMI" in the R package "SNFtool" (version 2.3.0) were

149 used to compute NMI (Liu et al., 2018a; Wang et al., 2014). Codes are provided in Script S1.

150 Tumor maps of cancer cell lines

151 We used the TumorMap website to create pan-cancer cell lines maps from the above integrated

152 data. TumorMap is an interactive website for assisting in exploring high-dimensional and

153 complicated omics data (https://tumormap.ucsc.edu/) (Newton et al., 2017). In TumorMap,

154 samples are distributed on a hexagonal grid based on their similarity and rendered using

155 Google's Map technology. The distances were used as input to generate a 2D layout of the

156 samples. We used features that NMI ranks top 20\% to calculate Euclidean similarity between

157 each cell line. The Euclidean similarity is equal to 1/ (1+ Euclidean distance). All parameters in

158 TumorMap were set default.

159

160 Results

161 Clustering based on single omics data

162 We initially clustered cell lines based on each type of omics data, which were mRNA, miRNA,

163 CNV, METHY and RPPA data. The optimal clustering numbers were set to 10 (Fig. 1 and Fig.

$164 \mathrm{~S} 1)$.

165 In the hierarchical clustering result of 901 cell lines by mRNA (Fig. 1A, Table S1 and Fig.

$166 \mathrm{~S} 1 \mathrm{~A})$, we found that one cluster was mainly formed from a single type of cancer (C7 [SKCM]).

167 Additionally, hematopoietic lymphatic malignancies were separated into two clusters, (C6 [ALL-

168 DLBC-MM] and C9 [LAML-LCML]). Cancer cell lines with histological similarity or proximity

169 tended to group together. These include C2: pan-gastrointestinal [COAD/READ-STAD], C4:

170 nervous system tumors [GBM-LGG and some SARC whose features were the same as them] and

171 C8: pan-gynecological [OV-UCEC and other SARC cell lines]. KEGG enrichment analysis 
172 indicated that $\mathrm{C} 1$ was enriched in human cytomegalovirus infection, transcriptional

173 misregulation in cancer, proteoglycans in cancer, TNF signaling pathway and NF-kappa B

174 signaling pathway (Figs. S2A and S2B). Meanwhile, the cell lines in C1 were enriched in GO

175 terms including reproductive system development and morphogenesis of embryonic epithelium 176 (Figs. S2C-S2H).

177 In the clustering result of miRNA data of 879 cell lines (Fig. 1B, Table S2 and Fig. S1B), five 178 clusters predominately contained a single cancer type (C2 [COAD/READ], C5 [STAD], C6 $179[\mathrm{HNSC}], \mathrm{C} 8[\mathrm{SKCM}]$ and C10 [NB]). And tumors of the hematopoietic lymphatic system were 180 distributed in two clusters (C4 [ALL-DLBC-LAML-LCML-MM] and C9 [ALL-DLBC181 LAML]). The significant signature of these two clusters were high expression of has-miR-142-

$1825 \mathrm{p}$ and has-miR-142-3p, which played an important role in lineage differentiation of 183 hematopoietic cells (Sharma, 2017).

184 CNV data sorted at the chromosome arm-level for 897 cell lines were divided into 10 clusters 185 through hierarchical clustering, four clusters mainly formed from a single cancer type (C3 [GBM], C5 [SKCM], C7 [PAAD] and C8 [SCLC]) (Fig. 1C, Table S3 and Fig. S1C). C8 was characterized by the deletion of chr3p and chr17p and the amplification of chr3q. This characterization had been reported in previous studies (Carter et al., 2017; George et al., 2015; Peifer et al., 2012). C1 and C10 were enriched for ALL, DLBC, LAML and LCML. We observed fewer alterations in $\mathrm{C} 1$ but more alterations in $\mathrm{C} 10$. For example, $\mathrm{C} 10$ was 191 characterized by chr8, chr19 and chr6 copy number increase.

192 Among the unsupervised clustering result of 755 cell lines using METHY data (Fig. 1D, Table 193 S4 and Fig. S1D), there was one cluster that virtually consisted of one cancer type (C7 [SKCM]). 194 Meanwhile, hematopoietic lymphatic malignancies were still enriched in two clusters (C3 195 [DLBC-MM] and C6 [ALL-LAML-LCML]). Cancer cell lines originating from same organ 196 often gathered in the same cluster, such as C2 [COAD/READ-STAD-PAAD], a group of 197 digestive system cancers whose common features were the high expression of CNKSR1, 198 FOLH1, ADGRG1, SMAD7, LRATD1 and MVP (Haffner et al., 2009; Ji et al., 2018; 
199 Kobayashi et al., 2006; Quadri et al., 2017; Slattery et al., 2010; Teng et al., 2017).

200 Additionally, squamous morphology cancer cell lines aggregated by METHY patterns (C10

201 [ESCA-HNSC]), particularly in terms of ARHGDIB and SEPTIN9 loss (Bennett et al., 2008).

202 In hierarchical clustering of RPPA data from 854 cell lines (Fig. 1E, Table S5 and Fig. S1E),

$203 \mathrm{C} 4$ [SKCM], C8[LUAD] and C10 [BRCA] mostly contained one cancer type. The characteristics 204 of $\mathrm{C} 10$ in this analysis had high level of ER, GATA3, AR, ERBB2, FASN, PREX1, CDH1 and 205 CLDN7, and low level of CAV1 (Barrio-Real et al., 2016; Neve et al., 2006; Taherian-Fard et 206 al., 2015). Hematopoietic lymphatic malignancies were enriched in one cluster (C3 [ALL207 DLBC-LAML-LCML-MM]). Consistent with METHY analysis, a pan-gastrointestinal 208 carcinoma cluster with COAD/READ-STAD was gathered in C2, which had high level of 209 CDH1, CLDN7 and TYRO3, and a low level of CAV1 (Burgermeister et al., 2007; Di 210 Bartolomeo et al., 2016; Qin \& Qian, 2018). In addition, C7 was an enrichment cluster of 211 squamous morphology cancer cell lines, mostly made of HNSC and ESCA and was 212 characterized by high level of CDH1, CLDN7 and CAV1 (Ando et al., 2007; Bello et al., 2008; 213 Shah et al., 2009).

214 Interestingly, some cancer types, such as SKCM, were individually classified in all five omics 215 data, whereas some cancer types such as SCLC and BRCA were clustered individually only in 216 one or two omics data. This result indicates that exposed information of each omics data is 217 different at molecular level. According to investigation, SKCM is a paradigm of invasive cancer 218 characterized by the highest mutational frequency among all cancer types and a large 219 accumulation of changes in transcriptome (Cancer Genome Atlas N, 2015; Lawrence et al., 220 2013). Compared to other cancer cell lines, there are a large number of special molecular 221 characteristics in SKCM cell lines. For example, we found that the levels of miR-188-3p and 222 miR-514 were increased significantly, whereas in other cell lines, the levels of the two miRNA 223 were decreased. At the CNV level, amplification of chr7 was found in most SKCM cell lines. It 224 is generally known that several common mutations of SKCM, are on the chromosome 7 225 (Hayward et al., 2017). Moreover, pan-cancer clusters could be found based on mRNA, METHY 
226

227

228

229

230

231

232

233

234

235

236

237

238

239

240

241

242

243

244

245

246

247

248

249

250

251

252

and RPPA, but were not individually clustered in miRNA and CNV. This phenomenon was consistent with feature contributions of integrated multiple omics clustering, and was related to the fact that the characteristic information from mRNA, METHY and RPPA dataset were more representative.

\section{Integrated clustering based on multiple omics data}

By using SNF-CC, we integrated all five of omics datasets (mRNA, miRNA, CNV, METHY and RPPA) across 670 cell lines and identified 18 clusters (Fig. 2A, Table S6 and Fig. S3).

For these 18 clusters, 12 of them were dominated by a single cancer type (C1 [SCLC], C2[GBM], C4 [ALL], C6 [SARC], C7 [BRCA], C8 [ALL], C10 [MM], C12 [DLBC], C14 [LAML], C15 [SKCM], C16 [NB] and C17 [KIRC]) (Figs. 2A and 2B, Fig. S4). And each clusters also mixed with few amounts of other cancer types. Except SKCM, C15 also contained one glioblastoma multiforme cell line (LN229) with low level of VHL and high expression of has-miR-146a, has-miR-29b and has-miR-188-3p (Aurich et al., 2017). It is notable that although $\mathrm{SARC}$ is the dominant cancer types in $\mathrm{C6}$, the proportion within the cluster is relatively low. There were six clusters that dominated by two cancer types (C3 [PAAD-LUAD], C5 [HNSCESCA], C9 [LAML-LCML], C11 [COAD/READ-STAD], C13 [LUAD-LIHC] and C18 [OVUCEC]) (Figs. 2A and 2B, Fig. S4). On the one hand, the proportion of two dominant cancer types were almost equal in C3, C13 and C18. And C3 was characterized by high level of CDH1. On the other hand, in C5, C9 and C11, one of the two dominant cancer type was over 50\%. And C9 had high levels of VAV1 and STAT5A and low level of CTNNB1 (Bertagnolo et al., 2011; Harir et al., 2007; Ysebaert et al., 2006).

Three pan-cancer clusters influenced by organ of origin or cell morphology pattern were obtained. These clusters included pan-gastrointestinal cluster (C11 [COAD/READ-STAD]), pangynecological cluster (C18 [OV-UCEC]) and pan-squamous morphology carcinoma cluster (C5 [HNSC-ESCA]). For pan-gastrointestinal cluster (C11 [COAD/READ-STAD]), KEGG enrichment analysis results showed that these cell lines shared down-regulated in cytokinecytokine receptor interaction and TNF signaling pathway (Figs. 3A, 3B and File S1). And cell 
253 lines in C11 had high levels of protein binding involved in heterotypic cell-cell adhesion, 254 SNARE binding and G-protein beta-subunit binding in GO terms (Figs. 3C-3H and File S1).

255 Meanwhile, pan-squamous morphology carcinoma cell lines (C5 [HNSC-ESCA]) were 256 characterized by up-regulated of nicotine addiction and cell adhesion molecules pathway. And 257 these cell lines had high levels of CAV1, EGFR and ITGA2 (Ando et al., 2007; Song et al., 258 2015b).

259 We also observed two clusters with the same cancer type dispersed. For instance, cell lines 260 from ALL were divided into two clusters, C4 and C8, despite the common characteristics such as 261 Human T-cell leukemia virus 1 infection, Th17 cell differentiation, and TNF signaling pathway. 262 The ALL cell lines in C8 were enriched in KEGG terms including up-regulated in ECM-receptor 263 interaction, down-regulated in antigen processing and presentation pathway, while the ALL cell 264 lines in C4 had low level of cellular senescence (Figs. 3A, 3B and File S1). GO enrichment 265 analysis results showed that the ALL cell lines in C8 had low level of cell-cell junction and high 266 levels of calcium channel activity, while the ALL cell lines in C4 were down-regulated in growth 267 factor receptor binding and sulfur compound binding (Figs. 3C-3H and File S1). At other four 268 omics levels, the features of these two clusters were different as well. For example, the levels of 269 PTEN (a tumor suppressor gene), LCK and Syk (two immune-related genes) and has-miR-151$2705 \mathrm{p}$ (related to tumor invasion and metastasis) was completely inconsistent.

271 Integrated multiple omics clustering provided a global view of cancer types because it could 272 capture both shared and complementary information from each omics data. Several cancer types 273 which mixed together in one single omics data were divided in other single omics data or 274 integrated omics data. For example, BRCA and SCLC were mixed together based on miRNA 275 data, but they were separated into two distinct molecular clusters based on integrated omics data. 276 Besides, in single omics clustering, three pan-organ system clusters were only found based on 277 mRNA data and the pan-squamous morphology carcinoma cluster was only found based on 278 METHY and RPPA data. But pan-gastrointestinal cluster, pan-gynecological cluster and pan- 
279 squamous morphology carcinoma clusters were simultaneously identified by integrated multiple 280 omics clustering.

281 The relative contribution of each omics data to the integrated clustering was computed based 282 on the NMI value. On the basis of the top $20 \%$ statistical features from the five omics data, we 283 found that RPPA and mRNA contributed $32.24 \%$ and $29.62 \%$ respectively, followed by 284 METHY (16.24\%) (Fig. 2C and Table 3). This result demonstrated that mRNA and proteomics 285 data were particular important for cancer molecular classification. Meanwhile, more information 286 was showed based on mRNA and RPPA data than other omics data in single omics clustering. 287 For instance, pan-organ system clusters were identified based on mRNA and RPPA data, but not 288 in miRNA and CNV. This results indicated that mRNA and proteomics data could be preferred if 289 multiple omics data were not able to be measured simultaneously.

\section{The comparison of classification between cancer samples and cell lines}

291 We compared the classification results of 19 cancer types shared by cancer cell lines from CCLE 292 and patient samples from TCGA (Hoadley et al., 2018). Clusters of patient samples and cell lines 293 were divided into three types respectively, namely clusters dominated by single cancer type, pan294 cancer clusters and clusters mixed with other cancer types (Table 4).

295 For hematopoietic lymphatic malignancies, the classification of cancer cell lines is more 296 abundant than patient samples. For example, some LAML cell lines were clustered together in a 297 group, while others were mixed with LCML cell lines into another group (LAML-LCML) in our 298 findings. For patient samples, there is only one LAML group (Hoadley et al., 2018). The 299 classification of DLBC cell lines was consistent with patient samples. Just like hematopoietic 300 malignancies, the SARC patient samples were clustered individually into a group. However, for 301 cell lines, except gathering in a single group, a few other SARC cell lines were mixed with 302 GBM.

303 For most solid tumors, the classification of patient samples is generally more abundant and 304 diverse than the corresponding cell lines. In general, patient samples with same cancer type can 305 be divided into multiple groups, while cell lines with same cancer type are clustered in one 
306 group. For example, the samples of breast cancer were classified into three subgroups (chr8q 307 amp, HER2 amp and Luminal). In addition, there were a large number of BRCA samples

308 gathered with other cancer types in a mixed cluster. Except a few of BRCA cell lines were mixed 309 in a pan-gynecological cluster, whereas almost all BRCA cell lines were clustered in a single 310 group. And there are similar clustering results in gastrointestinal cancer and squamous cell 311 carcinoma. There were two pan-gastrointestinal groups and a single gastric cancer group in 312 patient samples (Hoadley et al., 2018). While most colorectal and gastric cancer cell lines were 313 clustered in a pan-gastrointestinal cluster without forming a STAD group in the classification 314 result of cell lines. Most patient samples of ESCA were divided into a pan-squamous 315 morphology carcinoma group and a pan-gastrointestinal group, while in our study, most ESCA 316 and HNSC cell lines were clustered in a pan-squamous morphology carcinoma cluster. This 317 indicates that not all molecular subtypes of patient samples can be represented by current panels 318 of cancer cell lines.

319 On the other hand, while the number of clustering groups were same, the types of clusters 320 were different in cell lines and patient samples of some cancer types. For example, there is a pan321 kidney group in the classification of patient samples. But this cluster was not in our results 322 because there is only one cell line associated with kidney cancer, renal clear cell carcinoma 323 (KIRC), in the CCLE database (Hoadley et al., 2018; Ricketts et al., 2018). Although there was 324 no pan-kidney cluster in our research, the KIRC cell lines were clustered individually in our 325 clustering results. And the patient samples of OV and UCEC were gathered in different clusters, 326 while cell lines of the two cancer types were clustered together in a pan-gynecological group. 327 GBM patient samples were clustered with LGG to form a pan-cancer group, however due to 328 lacking LGG cell lines, GBM cell lines were clustered individually. The classification of patient 329 samples in some cancer types, such as LIHC, LUSC and THCA, the clusters they formed were 330 dominated by single cancer type (Hoadley et al., 2018). However, the clusters formed by these 331 three types of cancer cell lines were mixed with large number of other cancer types. 
332 In general, due to the larger numbers of patients and the greater heterogeneity in TCGA 333 samples, the classification results of patient samples are more diverse and abundant than cancer 334 cell lines. It is clear that the existing cancer cell lines do not fully represent all the molecular 335 types of corresponding patient samples. However, in some cancer types, the classification of 336 patient samples and cell lines were consistent. This shows that cancer cell lines can represent 337 primary samples to some extent.

\section{The TumorMap landscape of pan-cancer cell lines}

339 We used TumorMap web tool to visualize the landscape of pan-cancer cell lines. The same 340 layout and four different color schemes (SNF-CC cluster, TCGA disease, Pan-organ system and 341 histology) were used to reveal that most cancer cell lines gathered based on organ systems and

342 histopathological similarity (Fig. 4). More nuance within a cancer type were apparent. The

343 SARC was widely distributed and separated into three parts. Most of them enriched in C6

344 (SARC), while others were fell into C2 (GBM) characterized by amplification of chr7p and C16 345 (NB) characterized by chr17q amplification (Figs. 4A and 4B). Additionally, major cell lines 346 from STAD were assembled in C11 (COAD/READ-STAD), but few gathered in C18 (OV347 UCEC) and C13 (LUAD-LIHC). Pan-organ system clusters and pan-squamous morphology 348 carcinoma cluster reported previously were shown on the map (Fig. 4C) (Berger et al., 2018; 349 Campbell et al., 2018; Liu et al., 2018b). We found that cell lines within C11 (COAD/READ350 STAD) and C5 (HNSC-ESCA) were tightly gathered, while cell lines within C18 (OV-UCEC) 351 were relatively dispersed. The TumorMap landscape showed that cancer cell lines with similar 352 histology characterization tended to get together, even though histological information were not 353 used during calculating similarities (Fig. 4D). The hematopoietic lymphatic malignancies were 354 remote from other cancer types on the map. This result underscored that the molecular 355 characteristics of hematopoietic lymphatic malignancies were different from other cancer types 356 (Fig. 4D). Moreover, C15 (SKCM) and C17 (KIRC) were also far away from other solid tumor 357 groups on the map. 
358 We downloaded the drug susceptibility data for 24 anticancer drugs across 504 cell lines in 359 CCLE database. We used TumorMap web tool to analyze the relationship between the drug 360 susceptibility and the pan-cancer clustering. We divided the analysis results into four types and 361 chose the representative drugs as examples (Fig. S5).

362 (1) These anticancer drugs have a strong effect on almost all cancer cell lines. For example, 363 LUAD-LIHC (C13), GBM (C2), SARC (C6), DLBC (C12), SKCM (C15), OV-UCEC (C18) and

364 365 366 367 368 369 370 371 372 373 374 375 376

\section{Discussion}

378 379 S5A). (Fig. S5D). HNSC-ESCA (C5) cell lines are sensitive to Paclitaxel, a broad-spectrum anticancer drug (Fig.

(2) Almost all cell lines are not sensitive to these drugs, for example, L-685458, a gammasecretase inhibitor (Fig. S5B).

(3) Only one cell line or few cell lines are sensitive to these anticancer drugs. For example, as a BRAF inhibitor, PLX4720 has an obvious effect on some SKCM (C15) cell lines, but has no effect on other cell lines (Fig. S5C).

(4) These anticancer drugs have a strong effect on many cancer cell lines, but have a weak effect on others. For example, RAF256 is a dual inhibitor of mutant BRAF and vascular endothelial growth factor receptor 2. This drug can inhibit proliferation of SKCM (C15), GBM (C2), LUAD-LIHC (C13), OV-UCEC (C18) and some COAD/READ-STAD (C11) cell lines

In this research, we provide a pan-cancer cell lines classification based on single and multiple omics data. First, unsupervised hierarchical clustering was performed using five omics data from CCLE database, involving 31 cancer types and more than 1000 cell lines, with each omics data showing different characterization. Next, we analyzed integrated multiple omics data of pancancer cell lines using SNF-CC method and ultimately clustered 24 cancer types into 18 groups. Moreover, we analyzed dominant cancer types and functional enrichment of each clusters. Then, the relative contribution of each omics data were calculated. We compared the classification of 
385 cancer cell lines and patient samples. Finally, we used TumorMap web tool to illustrate the 386 landscape of cancer cell line clusters.

387 Our study showed that clusters were strongly influenced by organ system and cell of origin.

388 Three pan-cancer cell line clusters: pan-gastrointestinal group, pan-gynecological group and pan389 squamous morphology carcinoma group were identified by integrated multiple omics clustering 390 simultaneously (Berger et al., 2018; Campbell et al., 2018; Liu et al., 2018b). Common

391 functional mechanism and multiple omics characterization in the same pan-cancer clusters may 392 contribute to potential clinical application value. The clusters obtained by integrated clustering 393 provided reference about treating the same disease with different therapies. On one hand, one 394 cancer type with different molecular features gathered in different clusters. Although these cell 395 lines belong to same cancer type, the treatment therapies based on molecular characterizations 396 may be different. On the other hand, the treatment of a cluster containing multiple cancer types 397 may be the same. The comprehensive analysis about cancer classification could be used to 398 elucidate potential disease mechanism and provide additional guidance for molecular treatments.

399 Cancer cell lines have been commonly used as in vitro models of tumors in biomedical 400 research, however, the reliability has been doubted. The comparison of molecular classification 401 between cancer cell lines and patient samples from TCGA provided a valuable insight into the 402 reliability of cell lines as samples. While the overall classification of cell lines and samples were 403 quite similar, samples from cancer patients were generally more diverse and abundant than cell 404 lines. In some types of cancer, the number of molecular groups in patient samples were more 405 than the corresponding cancer types of cell lines, while in others, the molecular classification of 406 patient samples matched the corresponding molecular groups of cell lines. Our study provides 407 researchers with a widely comparison of pan-cancer cell lines and primary samples.

408 We also presented that mRNA and proteomics data were more strongly grouped in terms of 409 classification by cancer type than other omics data. This is meaningful for biologists and 410 oncologists choosing what types of omics data they need for their particular analysis.

\section{Conclusions}


413 In summary, we provide a novel multi-dimensional landscape of cancer cell lines, and an 414 approach to evaluate the importance of omic features in cancer classification. This research is 415 crucial for treating same cancer with different therapies based on molecular characteristics. The 416 comparison of molecular classification between pan-cancer cell lines and patient samples 417 represents a valuable resource for the reliability of available cell lines as model of tumors. With 418 the lower cost of omics analyses and the development of high-throughput omics technologies, 419 integrated more omics data for cancer classification could be applied in clinical diagnosis and 420 guide personalized treatment.

421 
422

423

424

425

426

427

428

429

430

431

432

433

434

435

436

437

438

439

440

441

442

443

444

445

446

447

448

449

450

451

452

453

454

455

456

457

458

459

460

461

462

\section{References}

Ando T, Ishiguro H, Kimura M, Mitsui A, Mori Y, Sugito N, Tomoda K, Mori R, Harada K, Katada T, Ogawa R, Fujii Y, and Kuwabara Y. 2007. The overexpression of caveolin-1 and caveolin-2 correlates with a poor prognosis and tumor progression in esophageal squamous cell carcinoma. Oncology Reports 18:601-609

Aurich MK, Fleming RMT, and Thiele I. 2017. A systems approach reveals distinct metabolic strategies among the NCI-60 cancer cell lines. Plos Computational Biology 13: e1005698 DOI: 10.1371/journal.pcbi.1005698.

Barrio-Real L, Wertheimer E, Garg R, Abba MC, and Kazanietz MG. 2016. Characterization of a P-Rex1 gene signature in breast cancer cells. Oncotarget 7:51335-51348 DOI: 10.18632/oncotarget.10285.

Bello IO, Vilen ST, Niinimaa A, Kantola S, Soini Y, and Salo T. 2008. Expression of claudins 1, 4, 5, and 7 and occludin, and relationship with prognosis in squamous cell carcinoma of the tongue. Human Pathology 39:1212-1220 DOI: 10.1016/j.humpath.2007.12.015.

Bennett KL, Karpenko M, Lin MT, Claus R, Arab K, Dyckhoff G, Plinkert P, Herpel E, Smiraglia D, and Plass C. 2008. Frequently methylated tumor suppressor genes in head and neck squamous cell carcinoma. Cancer Research 68:4494-4499 DOI: 10.1158/00085472.CAN-07-6509.

Berger AC, Korkut A, Kanchi RS, Hegde AM, Lenoir W, Liu WB, Liu YX, Fan HH, Shen H, Ravikumar V, Rao A, Schultz A, Li XB, Sumazin P, Williams C, Mestdagh P, Gunaratne PH, Yau C, Bowlby R, Robertson AG, Tiezzi DG, Wang C, Cherniack AD, Godwin AK, Kuderer NM, Rader JS, Zuna RE, Sood AK, Lazar AJ, Ojesina AI, Adebamowo C, Adebamowo SN, Baggerly KA, Chen TW, Chiu HS, Lefever S, Liu L, MacKenzie K, Orsulic S, Roszik J, Shelley CS, Song QQ, Vellano CP, Wentzensen N, Weinstein JN, Mills GB, Levine DA, Akbani R, and Network CGAR. 2018. A Comprehensive PanCancer Molecular Study of Gynecologic and Breast Cancers. Cancer Cell 33:690-705 DOI: 10.1016/j.ccell.2018.03.014.

Bertagnolo V, Nika E, Brugnoli F, Bonora M, Grassilli S, Pinton P, and Capitani S. 2011. Vav1 is a crucial molecule in monocytic/macrophagic differentiation of myeloid leukemiaderived cells. Cell and Tissue Research 345:163-175 DOI: 10.1007/s00441-011-1195-5.

Burgermeister E, Xing XB, Rocken C, Juhasz M, Chen J, Hiber M, Mair K, Shatz M, Liscovitch M, Schmid RM, and Ebert MPA. 2007. Differential expression and function of caveolin1 in human gastric cancer progression. Cancer Research 67:8519-8526 DOI:

10.1158/0008-5472.CAN-07-1125.

Campbell JD, Yau C, Bowlby R, Liu YX, Brennan K, Fan HH, Taylor AM, Wang C, Walter V, Akbani R, Byers LA, Creighton CJ, Coarfa C, Shih J, Cherniack AD, Gevaert O, Prunello M, Shen H, Anur P, Chen JH, Cheng H, Hayes DN, Bullman S, Pedamallu CS, Ojesina AI, Sadeghi S, Mungall KL, Robertson AG, Benz C, Schultz A, Kanchi RS, Gay CM, Hegde A, Diao LX, Wang J, Ma WC, Sumazin P, Chiu HS, Chen TW, Gunaratne P, Donehower L, Rader JS, Zuna R, Al-Ahmadie H, Lazar AJ, Flores ER, Tsai KY, Zhou JH, Rustgi AK, Drill E, Shen RL, Wong CK, Stuart JM, Laird PW, Hoadley KA, 
463

464

465

466

467

468

469

470

471

472

473

474

475

476

477

478

479

480

481

482

483

484

485

486

487

488

489

490

491

492

493

494

495

496

497

498

499

500

501

502

503

Weinstein JN, Peto M, Pickering CR, Chen Z, Waes C, and Network CGAR. 2018. Genomic, Pathway Network, and Immunologic Features Distinguishing Squamous Carcinomas. Cell Reports 23:194-212 DOI: 10.1016/j.celrep.2018.03.063.

Cancer Genome Atlas N. 2015. Genomic Classification of Cutaneous Melanoma. Cell 161:16811696 DOI: 10.1016/j.cell.2015.05.044.

Carter L, Rothwell DG, Mesquita B, Smowton C, Leong HS, Fernandez-Gutierrez F, Li Y, Burt DJ, Antonello J, Morrow CJ, Hodgkinson CL, Morris K, Priest L, Carter M, Miller C, Hughes A, Blackhall F, Dive C, and Brady G. 2017. Molecular analysis of circulating tumor cells identifies distinct copy-number profiles in patients with chemosensitive and chemorefractory small-cell lung cancer. Nature Medicine 23:114-119 DOI: 10.1038/nm.4239.

Charrad M, Ghazzali N, Boiteau V, and Niknafs A. 2014. Nbclust: An R Package for Determining the Relevant Number of Clusters in a Data Set. Journal of Statistical Software 61:1-36.

Di Bartolomeo M, Pietrantonio F, Pellegrinelli A, Martinetti A, Mariani L, Daidone MG, Bajetta E, Pelosi G, de Braud F, Floriani I, and Miceli R. 2016. Osteopontin, E-cadherin, and beta-catenin expression as prognostic biomarkers in patients with radically resected gastric cancer. Gastric Cancer 19:412-420 DOI: 10.1007/s10120-015-0495-y.

Domcke S, Sinha R, Levine DA, Sander C and Schultz N. 2013. Evaluating cell lines as tumour models by comparison of genomic profiles. Nature Communications 4:2126 DOI: $10.1038 /$ ncomms 3126 .

Dozmorov MG. 2018. Disease classification: from phenotypic similarity to integrative genomics and beyond. Briefings in Bioinformatics DOI: 10.1093/bib/bby049.

George J, Lim JS, Jang SJ, Cun Y, Ozretic L, Kong G, Leenders F, Lu X, Fernandez-Cuesta L, Bosco G, Muller C, Dahmen I, Jahchan NS, Park KS, Yang D, Karnezis AN, Vaka D, Torres A, Wang MS, Korbel JO, Menon R, Chun SM, Kim D, Wilkerson M, Hayes N, Engelmann D, Putzer B, Bos M, Michels S, Vlasic I, Seidel D, Pinther B, Schaub P, Becker C, Altmuller J, Yokota J, Kohno T, Iwakawa R, Tsuta K, Noguchi M, Muley T, Hoffmann H, Schnabel PA, Petersen I, Chen Y, Soltermann A, Tischler V, Choi CM, Kim YH, Massion PP, Zou Y, Jovanovic D, Kontic M, Wright GM, Russell PA, Solomon B, Koch I, Lindner M, Muscarella LA, la Torre A, Field JK, Jakopovic M, Knezevic J, Castanos-Velez E, Roz L, Pastorino U, Brustugun OT, Lund-Iversen M, Thunnissen E, Kohler J, Schuler M, Botling J, Sandelin M, Sanchez-Cespedes M, Salvesen HB, Achter V, Lang U, Bogus M, Schneider PM, Zander T, Ansen S, Hallek M, Wolf J, Vingron M, Yatabe Y, Travis WD, Nurnberg P, Reinhardt C, Perner S, Heukamp L, Buttner R, Haas SA, Brambilla E, Peifer M, Sage J, and Thomas RK. 2015. Comprehensive genomic profiles of small cell lung cancer. Nature 524:47-53 DOI: 10.1038/nature14664.

Ghandi M, Huang FW, Jane-Valbuena J, Kryukov GV, Lo CC, McDonald ER, 3rd, Barretina J, Gelfand ET, Bielski CM, Li H, Hu K, Andreev-Drakhlin AY, Kim J, Hess JM, Haas BJ, Aguet F, Weir BA, Rothberg MV, Paolella BR, Lawrence MS, Akbani R, Lu Y, Tiv HL, Gokhale PC, de Weck A, Mansour AA, Oh C, Shih J, Hadi K, Rosen Y, Bistline J, 
504

505

506

507

508

509

510

511

512

513

514

515

516

517

518

519

520

521

522

523

524

525

526

527

528

529

530

531

532

533

534

535

536

537

538

539

540

541

542

543

544

Venkatesan K, Reddy A, Sonkin D, Liu M, Lehar J, Korn JM, Porter DA, Jones MD, Golji J, Caponigro G, Taylor JE, Dunning CM, Creech AL, Warren AC, McFarland JM, Zamanighomi M, Kauffmann A, Stransky N, Imielinski M, Maruvka YE, Cherniack AD, Tsherniak A, Vazquez F, Jaffe JD, Lane AA, Weinstock DM, Johannessen CM, Morrissey MP, Stegmeier F, Schlegel R, Hahn WC, Getz G, Mills GB, Boehm JS, Golub TR, Garraway LA, and Sellers WR. 2019. Next-generation characterization of the Cancer Cell Line Encyclopedia. Nature 569:503-508 DOI: 10.1038/s41586-019-1186-3.

Haffner MC, Kronberger IE, Ross JS, Sheehan CE, Zitt M, Muhlmann G, Ofner D, Zelger B, Ensinger C, Yang XMJ, Geley S, Margreiter R, and Bander NH. 2009. Prostate-specific membrane antigen expression in the neovasculature of gastric and colorectal cancers. Human Pathology 40:1754-1761 DOI: 10.1016/j.humpath.2009.06.003.

Harir N, Pecquet C, Kerenyi M, Sonneck K, Kovacic B, Nyga R, Brevet M, Dhennin I, Gouilleux-Gruart V, Beug H, Valent P, Lassoued K, Moriggl R, and Gouilleux F. 2007. Constitutive activation of Stat5 promotes its cytoplasmic localization and association with PI3-kinase in myeloid leukemias. Blood 109:1678-1686 DOI: 10.1182/blood-200601-029918.

Hayward NK, Wilmott JS, Waddell N, Johansson PA, Field MA, Nones K, Patch AM, Kakavand H, Alexandrov LB, Burke H, Jakrot V, Kazakoff S, Holmes O, Leonard C, Sabarinathan R, Mularoni L, Wood S, Xu Q, Waddell N, Tembe V, Pupo GM, De Paoli-Iseppi R, Vilain RE, Shang P, Lau LMS, Dagg RA, Schramm SJ, Pritchard A, Dutton-Regester K, Newell F, Fitzgerald A, Shang CA, Grimmond SM, Pickett HA, Yang JY, Stretch JR, Behren A, Kefford RF, Hersey P, Long GV, Cebon J, Shackleton M, Spillane AJ, Saw RPM, Lopez-Bigas N, Pearson JV, Thompson JF, Scolyer RA, and Mann GJ. 2017. Whole-genome landscapes of major melanoma subtypes. Nature 545:175-180 DOI: 10.1038/nature22071.

Heim D, Budczies J, Stenzinger A, Treue D, Hufnagl P, Denkert C, Dietel M, and Klauschen F. 2014. Cancer beyond organ and tissue specificity: next-generation-sequencing gene mutation data reveal complex genetic similarities across major cancers. International Journal of Cancer 135:2362-2369.

Hoadley KA, Yau C, Hinoue T, Wolf DM, Lazar AJ, Drill E, Shen R, Taylor AM, Cherniack AD, Thorsson V, Akbani R, Bowlby R, Wong CK, Wiznerowicz M, Sanchez-Vega F, Robertson AG, Schneider BG, Lawrence MS, Noushmehr H, Malta TM, Cancer Genome Atlas N, Stuart JM, Benz CC, and Laird PW. 2018. Cell-of-Origin Patterns Dominate the Molecular Classification of 10,000 Tumors from 33 Types of Cancer. Cell 173:291-304 e296 DOI: 10.1016/j.cell.2018.03.022.

Hoadley KA, Yau C, Wolf DM, Cherniack AD, Tamborero D, Ng S, Leiserson MDM, Niu BF, McLellan MD, Uzunangelov V, Zhang JS, Kandoth C, Akbani R, Shen H, Omberg L, Chu A, Margolin AA, van't Veer LJ, Lopez-Bigas N, Laird PW, Raphael BJ, Ding L, Robertson AG, Byers LA, Mills GB, Weinstein JN, Van Waes C, Chen Z, Collisson EA, Benz CC, Perou CM, Stuart JM, Abbott R, Abbott S, Aksoy BA, Aldape K, Ally A, Amin S, Anastassiou D, Auman JT, Baggerly KA, Balasundaram M, Balu S, Baylin SB,

Peer] reviewing PDF | (2019:12:43613:2:0:NEW 12 May 2020) 
545

546

547

548

549

550

551

552

553

554

555

556

557

558

559

560

561

562

563

564

565

566

567

568

569

570

571

572

573

574

575

576

577

578

579

580

581

582

583

584

585

Benz SC, Berman BP, Bernard B, Bhatt AS, Birol I, Black AD, Bodenheimer T, Bootwalla MS, Bowen J, Bressler R, Bristow CA, Brooks AN, Broom B, Buda E, Burton R, Butterfield YSN, Carlin D, Carter SL, Casasent TD, Chang K, Chanock S, Chin L, Cho DY, Cho J, Chuah E, Chun HJE, Cibulskis K, Ciriello G, Cleland J, Cline M, Craft B, Creighton CJ, Danilova L, Davidsen T, Davis C, Dees ND, Delehaunty K, Demchok JA, Dhalla N, DiCara D, Dinh H, Dobson JR, Dodda D, Doddapaneni H, Donehower L, Dooling DJ, Dresdner G, Drummond J, Eakin A, Edgerton M, Eldred JM, Eley G, Ellrott K, Fan C, Fei S, Felau I, Frazer S, Freeman SS, Frick J, Fronick CC, Fulton LL, Fulton R, Gabriel SB, Gao JJ, Gastier-Foster JM, Gehlenborg N, George M, Getz G, Gibbs R, Goldman M, Gonzalez-Perez A, Gross B, Guin R, Gunaratne P, Hadjipanayis A, Hamilton MP, Hamilton SR, Han L, Han Y, Harper HA, Haseley P, Haussler D, Hayes DN, Heiman DI, Helman E, Helsel C, Herbrich SM, Herman JG, Hinoue T, Hirst C, Hirst M, Holt RA, Hoyle AP, Iype L, Jacobsen A, Jeffreys SR, Jensen MA, Jones CD, Jones SJM, Ju ZL, Jung J, Kahles A, Kahn A, Kalicki-Veizer J, Kalra D, Kanchi KL, Kane DW, Kim H, Kim J, Knijnenburg T, Koboldt DC, Kovar C, Kramer R, Kreisberg R, Kucherlapati R, Ladanyi M, Lander ES, Larson DE, Lawrence MS, Lee D, Lee E, Lee S, Lee W, Lehmann KV, Leinonen K, Leraas KM, Lerner S, Levine DA, Lewis L, Ley TJ, Li HI, Li J, Li W, Liang H, Lichtenberg TM, Lin J, Lin L, Lin P, Liu WB, Liu YC, Liu YX, Lorenzi PL, Lu C, Lu YL, Luquette LJ, Ma S, Magrini VJ, Mahadeshwar HS, Mardis ER, Margolin A, Marra MA, Mayo M, McAllister C, McGuire SE, McMichael JF, Melott J, Meng SW, Meyerson M, Mieczkowski PA, Miller CA, Miller ML, Miller M, Moore RA, Morgan M, Morton D, Mose LE, Mungall AJ, Muzny D, Nguyen L, Noble MS, Noushmehr H, O'Laughlin M, Ojesina AI, Yang TO, Ozenberger B, Pantazi A, Parfenov M, Park PJ, Parker JS, Paull E, Pedamallu CS, Pihl T, Pohl C, Pot D, Protopopov A, Przytycka T, Radenbaugh A, Ramirez NC, Ramirez R, Ratsch G, Reid J, Ren XJ, Reva B, Reynolds SM, Rhie SK, Roach J, Rovira H, Ryan M, Saksena G, Salama S, Sander C, Santoso N, Schein JE, Schmidt H, Schultz N, Schumacher SE, Seidman J, Senbabaoglu Y, Seth S, Sharpe S, Shen RL, Sheth M, Shi Y, Shmulevich I, Silva GO, Simons JV, Sinha R, Sipahimalani P, Smith SM, Sofia HJ, Sokolov A, Soloway MG, Song XZ, Sougnez C, Spellman P, Staudt L, Stewart C, Stojanov P, Su XP, Sumer SO, Sun YC, Swatloski T, Tabak B, Tam A, Tan DH, Tang JB, Tarnuzzer R, Taylor BS, Thiessen N, Thorsson V, Triche T, Van Den Berg DJ, Vandin F, Varhol RJ, Vaske CJ, Veluvolu U, Verhaak R, Voet D, Walker J, Wallis JW, Waltman P, Wan YH, Wang M, Wang WY, Wang ZN, Waring S, Weinhold N, Weisenberger DJ, Wendl MC, Wheeler D, Wilkerson MD, Wilson RK, Wise L, Wong A, Wu CJ, Wu CC, Wu HT, Wu JY, Wylie T, Xi L, Xi RB, Xia Z, Xu AW, Yang D, Yang LM, Yang LX, Yang Y, Yao J, Yao R, Ye K, Yoshihara K, Yuan Y, Yung AK, Zack T, Zeng D, Zenklusen JC, Zhang HL, Zhang JH, Zhang NX, Zhang QY, Zhang W, Zhao W, Zheng SY, Zhu J, Zmuda E, Zou LH, and Network CGAR. 2014. Multiplatform Analysis of 12 Cancer Types Reveals Molecular Classification within and across Tissues of Origin. Cell 158:929-944 DOI: 10.1016/j.cell.2014.06.049.

Peer) reviewing PDF | (2019:12:43613:2:0:NEW 12 May 2020) 
586

587

588

589

590

591

592

593

594

595

596

597

598

599

600

601

602

603

604

605

606

607

608

609

610

611

612

613

614

615

616

617

618

619

620

621

622

623

624

625

626

International Cancer Genome C, Hudson TJ, Anderson W, Artez A, Barker AD, Bell C, Bernabe RR, Bhan MK, Calvo F, Eerola I, Gerhard DS, Guttmacher A, Guyer M, Hemsley FM, Jennings JL, Kerr D, Klatt P, Kolar P, Kusada J, Lane DP, Laplace F, Youyong L, Nettekoven G, Ozenberger B, Peterson J, Rao TS, Remacle J, Schafer AJ, Shibata T, Stratton MR, Vockley JG, Watanabe K, Yang H, Yuen MM, Knoppers BM, Bobrow M, Cambon-Thomsen A, Dressler LG, Dyke SO, Joly Y, Kato K, Kennedy KL, Nicolas P, Parker MJ, Rial-Sebbag E, Romeo-Casabona CM, Shaw KM, Wallace S, Wiesner GL, Zeps N, Lichter P, Biankin AV, Chabannon C, Chin L, Clement B, de Alava E, Degos F, Ferguson ML, Geary P, Hayes DN, Hudson TJ, Johns AL, Kasprzyk A, Nakagawa H, Penny R, Piris MA, Sarin R, Scarpa A, Shibata T, van de Vijver M, Futreal PA, Aburatani H, Bayes M, Botwell DD, Campbell PJ, Estivill X, Gerhard DS, Grimmond SM, Gut I, Hirst M, Lopez-Otin C, Majumder P, Marra M, McPherson JD, Nakagawa H, Ning Z, Puente XS, Ruan Y, Shibata T, Stratton MR, Stunnenberg HG, Swerdlow H, Velculescu VE, Wilson RK, Xue HH, Yang L, Spellman PT, Bader GD, Boutros PC, Campbell PJ, Flicek P, Getz G, Guigo R, Guo G, Haussler D, Heath S, Hubbard TJ, Jiang T, Jones SM, Li Q, Lopez-Bigas N, Luo R, Muthuswamy L, Ouellette BF, Pearson JV, Puente XS, Quesada V, Raphael BJ, Sander C, Shibata T, Speed TP, Stein LD, Stuart JM, Teague JW, Totoki Y, Tsunoda T, Valencia A, Wheeler DA, Wu H, Zhao S, Zhou G, Stein LD, Guigo R, Hubbard TJ, Joly Y, Jones SM, Kasprzyk A, Lathrop M, LopezBigas N, Ouellette BF, Spellman PT, Teague JW, Thomas G, Valencia A, Yoshida T, Kennedy KL, Axton M, Dyke SO, Futreal PA, Gerhard DS, Gunter C, Guyer M, Hudson TJ, McPherson JD, Miller LJ, Ozenberger B, Shaw KM, Kasprzyk A, Stein LD, Zhang J, Haider SA, Wang J, Yung CK, Cros A, Liang Y, Gnaneshan S, Guberman J, Hsu J, Bobrow M, Chalmers DR, Hasel KW, Joly Y, Kaan TS, Kennedy KL, Knoppers BM, Lowrance WW, Masui T, Nicolas P, Rial-Sebbag E, Rodriguez LL, Vergely C, Yoshida T, Grimmond SM, Biankin AV, Bowtell DD, Cloonan N, deFazio A, Eshleman JR, Etemadmoghadam D, Gardiner BB, Kench JG, Scarpa A, Sutherland RL, Tempero MA, Waddell NJ, Wilson PJ, McPherson JD, Gallinger S, Tsao MS, Shaw PA, Petersen GM, Mukhopadhyay D, Chin L, DePinho RA, Thayer S, Muthuswamy L, Shazand K, Beck T, Sam M, Timms L, Ballin V, Lu Y, Ji J, Zhang X, Chen F, Hu X, Zhou G, Yang Q, Tian G, Zhang L, Xing X, Li X, Zhu Z, Yu Y, Yu J, Yang H, Lathrop M, Tost J, Brennan P, Holcatova I, Zaridze D, Brazma A, Egevard L, Prokhortchouk E, Banks RE, Uhlen M, Cambon-Thomsen A, Viksna J, Ponten F, Skryabin K, Stratton MR, Futreal PA, Birney E, Borg A, Borresen-Dale AL, Caldas C, Foekens JA, Martin S, Reis-Filho JS, Richardson AL, Sotiriou C, Stunnenberg HG, Thoms G, van de Vijver M, van't Veer L, Calvo F, Birnbaum D, Blanche H, Boucher P, Boyault S, Chabannon C, Gut I, MassonJacquemier JD, Lathrop M, Pauporte I, Pivot X, Vincent-Salomon A, Tabone E, Theillet C, Thomas G, Tost J, Treilleux I, Calvo F, Bioulac-Sage P, Clement B, Decaens T, Degos F, Franco D, Gut I, Gut M, Heath S, Lathrop M, Samuel D, Thomas G, ZucmanRossi J, Lichter P, Eils R, Brors B, Korbel JO, Korshunov A, Landgraf P, Lehrach H, Pfister S, Radlwimmer B, Reifenberger G, Taylor MD, von Kalle C, Majumder PP, Sarin

PeerJ reviewing PDF | (2019:12:43613:2:0:NEW 12 May 2020) 
627

628

629

630

631

632

633

634

635

636

637

638

639

640

641

642

643

644

645

646

647

648

649

650

651

652

653

654

655

656

657

658

659

660

661

662

663

664

665

666

667

R, Rao TS, Bhan MK, Scarpa A, Pederzoli P, Lawlor RA, Delledonne M, Bardelli A, Biankin AV, Grimmond SM, Gress T, Klimstra D, Zamboni G, Shibata T, Nakamura Y, Nakagawa H, Kusada J, Tsunoda T, Miyano S, Aburatani H, Kato K, Fujimoto A, Yoshida T, Campo E, Lopez-Otin C, Estivill X, Guigo R, de Sanjose S, Piris MA, Montserrat E, Gonzalez-Diaz M, Puente XS, Jares P, Valencia A, Himmelbauer H, Quesada V, Bea S, Stratton MR, Futreal PA, Campbell PJ, Vincent-Salomon A, Richardson AL, Reis-Filho JS, van de Vijver M, Thomas G, Masson-Jacquemier JD, Aparicio S, Borg A, Borresen-Dale AL, Caldas C, Foekens JA, Stunnenberg HG, van't Veer L, Easton DF, Spellman PT, Martin S, Barker AD, Chin L, Collins FS, Compton CC, Ferguson ML, Gerhard DS, Getz G, Gunter C, Guttmacher A, Guyer M, Hayes DN, Lander ES, Ozenberger B, Penny R, Peterson J, Sander C, Shaw KM, Speed TP, Spellman PT, Vockley JG, Wheeler DA, Wilson RK, Hudson TJ, Chin L, Knoppers BM, Lander ES, Lichter P, Stein LD, Stratton MR, Anderson W, Barker AD, Bell C, Bobrow M, Burke W, Collins FS, Compton CC, DePinho RA, Easton DF, Futreal PA, Gerhard DS, Green AR, Guyer M, Hamilton SR, Hubbard TJ, Kallioniemi OP, Kennedy KL, Ley TJ, Liu ET, Lu Y, Majumder P, Marra M, Ozenberger B, Peterson J, Schafer AJ, Spellman PT, Stunnenberg HG, Wainwright BJ, Wilson RK, and Yang H. 2010. International network of cancer genome projects. Nature 464:993-998 DOI: 10.1038/nature08987.

Ji B, Feng YF, Sun Y, Ji DJ, Qian WW, Zhang ZY, Wang QY, Zhang Y, Zhang C, and Sun YM. 2018. GPR56 promotes proliferation of colorectal cancer cells and enhances metastasis via epithelial-mesenchymal transition through PI3K/AKT signaling activation. Oncology Reports 40:1885-1896 DOI: 10.3892/or.2018.6582.

Kobayashi T, Masaki T, Sugiyama M, Atomi Y, Furukawa Y, and Nakamura Y. 2006. A gene encoding a family with sequence similarity 84, member A (FAM84A) enhanced migration of human colon cancer cells. International Journal of Oncology 29:341-347.

Koboldt DC, Fulton RS, McLellan MD, Schmidt H, Kalicki-Veizer J, McMichael JF, Fulton LL, Dooling DJ, Ding L, Mardis ER, Wilson RK, Ally A, Balasundaram M, Butterfield YSN, Carlsen R, Carter C, Chu A, Chuah E, Chun HJE, Coope RJN, Dhalla N, Guin R, Hirst C, Hirst M, Holt RA, Lee D, Li HYI, Mayo M, Moore RA, Mungall AJ, Pleasance E, Robertson AG, Schein JE, Shafiei A, Sipahimalani P, Slobodan JR, Stoll D, Tam A, Thiessen N, Varhol RJ, Wye N, Zeng T, Zhao YJ, Birol I, Jones SJM, Marra MA, Cherniack AD, Saksena G, Onofrio RC, Pho NH, Carter SL, Schumacher SE, Tabak B, Hernandez B, Gentry J, Nguyen H, Crenshaw A, Ardlie K, Beroukhim R, Winckler W, Getz G, Gabriel SB, Meyerson M, Chin L, Park PJ, Kucherlapati R, Hoadley KA, Auman JT, Fan C, Turman YJ, Shi Y, Li L, Topal MD, He XP, Chao HH, Prat A, Silva GO, Iglesia MD, Zhao W, Usary J, Berg JS, Adams M, Booker J, Wu JY, Gulabani A, Bodenheimer T, Hoyle AP, Simons JV, Soloway MG, Mose LE, Jefferys SR, Balu S, Parker JS, Hayes DN, Perou CM, Malik S, Mahurkar S, Shen H, Weisenberger DJ, Triche T, Lai PH, Bootwalla MS, Maglinte DT, Berman BP, Van den Berg DJ, Baylin SB, Laird PW, Creighton CJ, Donehower LA, Getz G, Noble M, Voet D, Saksena G, 
668

669

670

671

672

673

674

675

676

677

678

679

680

681

682

683

684

685

686

687

688

689

690

691

692

693

694

695

696

697

698

699

700

701

702

703

704

705

706

707

708
Gehlenborg N, DiCara D, Zhang JH, Zhang HL, Wu CJ, Liu SY, Lawrence MS, Zou LH, Sivachenko A, Lin P, Stojanov P, Jing R, Cho J, Sinha R, Park RW, Nazaire MD, Robinson J, Thorvaldsdottir H, Mesirov J, Park PJ, Chin L, Reynolds S, Kreisberg RB, Bernard B, Bressler R, Erkkila T, Lin J, Thorsson V, Zhang W, Shmulevich I, Ciriello G, Weinhold N, Schultz N, Gao JJ, Cerami E, Gross B, Jacobsen A, Sinha R, Aksoy BA, Antipin Y, Reva B, Shen RL, Taylor BS, Ladanyi M, Sander C, Anur P, Spellman PT, Lu YL, Liu WB, Verhaak RRG, Mills GB, Akbani R, Zhang NX, Broom BM, Casasent TD, Wakefield C, Unruh AK, Baggerly K, Coombes K, Weinstein JN, Haussler D, Benz CC, Stuart JM, Benz SC, Zhu JC, Szeto CC, Scott GK, Yau C, Paul EO, Carlin D, Wong C, Sokolov A, Thusberg J, Mooney S, Ng S, Goldstein TC, Ellrott K, Grifford M, Wilks C, Ma S, Craft B, Yan CH, Hu Y, Meerzaman D, Gastier-Foster JM, Bowen J, Ramirez NC, Black AD, Pyatt RE, White P, Zmuda EJ, Frick J, Lichtenberg T, Brookens R, George MM, Gerken MA, Harper HA, Leraas KM, Wise LJ, Tabler TR, McAllister C, Barr T, Hart-Kothari M, Tarvin K, Saller C, Sandusky G, Mitchell C, Iacocca MV, Brown J, Rabeno B, Czerwinski C, Petrelli N, Dolzhansky O, Abramov M, Voronina O, Potapova O, Marks JR, Suchorska WM, Murawa D, Kycler W, Ibbs M, Korski K, Spychala A, Murawa P, Brzezinski JJ, Perz H, Lazniak R, Teresiak M, Tatka H, Leporowska E, Bogusz-Czerniewicz M, Malicki J, Mackiewicz A, Wiznerowicz M, Le XV, Kohl B, Tien NV, Thorp R, Bang NV, Sussman H, Phu BD, Hajek R, Hung NP, Tran VTP, Thang HQ, Khan KZ, Penny R, Mallery D, Curley E, Shelton C, Yena P, Ingle JN, Couch FJ, Lingle WL, King TA, Gonzalez-Angulo AM, Mills GB, Dyer MD, Liu SY, Meng XL, Patangan M, Waldman F, Stoppler H, Rathmell WK, Thorne L, Huang M, Boice L, Hill A, Morrison C, Gaudioso C, Bshara W, Daily K, Egea SC, Pegram MD, Gomez-Fernandez C, Dhir R, Bhargava R, Brufsky A, Shriver CD, Hooke JA, Campbell JL, Mural RJ, Hu H, Somiari S, Larson C, Deyarmin B, Kvecher L, Kovatich AJ, Ellis MJ, King TA, Hu H, Couch FJ, Mural RJ, Stricker T, White K, Olopade O, Ingle JN, Luo CQ, Chen YQ, Marks JR, Waldman F, Wiznerowicz M, Bose R, Chang LW, Beck AH, Gonzalez-Angulo AM, Pihl T, Jensen M, Sfeir R, Kahn A, Chu A, Kothiyal P, Wang ZN, Snyder E, Pontius J, Ayala B, Backus M, Walton J, Baboud J, Berton D, Nicholls M, Srinivasan D, Raman R, Girshik S, Kigonya P, Alonso S, Sanbhadti R, Barletta S, Pot D, Sheth M, Demchok JA, Shaw KRM, Yang LM, Eley G, Ferguson ML, Tarnuzzer RW, Zhang JS, Dillon LAL, Buetow K, Fielding P, Ozenberger BA, Guyer MS, Sofia HJ, Palchik JD, and Network CGA. 2012. Comprehensive molecular portraits of human breast tumours. Nature 490:61-70 DOI: 10.1038/nature11412.

Lawrence MS, Stojanov P, Polak P, Kryukov GV, Cibulskis K, Sivachenko A, Carter SL, Stewart C, Mermel CH, Roberts SA, Kiezun A, Hammerman PS, McKenna A, Drier Y, Zou LH, Ramos AH, Pugh TJ, Stransky N, Helman E, Kim J, Sougnez C, Ambrogio L, Nickerson E, Shefler E, Cortes ML, Auclair D, Saksena G, Voet D, Noble M, DiCara D, Lin P, Lichtenstein L, Heiman DI, Fennell T, Imielinski M, Hernandez B, Hodis E, Baca S, Dulak AM, Lohr J, Landau DA, Wu CJ, Melendez-Zajgla J, Hidalgo-Miranda A, Koren A, McCarroll SA, Mora J, Crompton B, Onofrio R, Parkin M, Winckler W, Ardlie 
709

710

711

712

713

714

715

716

717

718

719

720

721

722

723

724

725

726

727

728

729

730

731

732

733

734

735

736

737

738

739

740

741

742

743

744

745

746

747

748

749

K, Gabriel SB, Roberts CWM, Biegel JA, Stegmaier K, Bass AJ, Garraway LA, Meyerson M, Golub TR, Gordenin DA, Sunyaev S, Lander ES, and Getz G. 2013. Mutational heterogeneity in cancer and the search for new cancer-associated genes. Nature 499:214-218 DOI: 10.1038/nature12213.

Li J, Zhao W, Akbani R, Liu W, Ju Z, Ling S, Vellano CP, Roebuck P, Yu Q, Eterovic AK, Byers LA, Davies MA, Deng W, Gopal YN, Chen G, von Euw EM, Slamon D, Conklin D, Heymach JV, Gazdar AF, Minna JD, Myers JN, Lu Y, Mills GB, and Liang H. 2017. Characterization of Human Cancer Cell Lines by Reverse-phase Protein Arrays. Cancer Cell 31:225-239 DOI: 10.1016/j.ccell.2017.01.005.

Liu K, Guo J, Liu K, Fan P, Zeng Y, Xu C, Zhong J, Li Q, and Zhou Y. 2018a. Integrative analysis reveals distinct subtypes with therapeutic implications in KRAS-mutant lung adenocarcinoma. EBioMedicine 36:196-208 DOI: 10.1016/j.ebiom.2018.09.034.

Liu Y, Sethi NS, Hinoue T, Schneider BG, Cherniack AD, Sanchez-Vega F, Seoane JA, Farshidfar F, Bowlby R, Islam M, Kim J, Chatila W, Akbani R, Kanchi RS, Rabkin CS, Willis JE, Wang KK, McCall SJ, Mishra L, Ojesina AI, Bullman S, Pedamallu CS, Lazar AJ, Sakai R, Thorsson V, Bass AJ, Laird PW, and Network CGAR. 2018b. Comparative Molecular Analysis of Gastrointestinal Adenocarcinomas. Cancer Cell 33:721-735 DOI: 10.1016/j.ccell.2018.03.010.

Mermel CH, Schumacher SE, Hill B, Meyerson ML, Beroukhim R, and Getz G. 2011.

GISTIC2.0 facilitates sensitive and confident localization of the targets of focal somatic copy-number alteration in human cancers. Genome Biology 12:R41 DOI: 10.1186/gb2011-12-4-r41.

Monti S, Tamayo P, Mesirov J, and Golub T. 2003. Consensus clustering: A resampling-based method for class discovery and visualization of gene expression microarray data. Machine Learning 52:91-118 DOI: 10.1023/A:1023949509487.

Neve RM, Chin K, Fridlyand J, Yeh J, Baehner FL, Fevr T, Clark L, Bayani N, Coppe JP, Tong F, Speed T, Spellman PT, DeVries S, Lapuk A, Wang NJ, Kuo WL, Stilwell JL, Pinkel D, Albertson DG, Waldman FM, McCormick F, Dickson RB, Johnson MD, Lippman M, Ethier S, Gazdar A, and Gray JW. 2006. A collection of breast cancer cell lines for the study of functionally distinct cancer subtypes. Cancer Cell 10:515-527 DOI: 10.1016/j.ccr.2006.10.008.

Newton Y, Novak AM, Swatloski T, McColl DC, Chopra S, Graim K, Weinstein AS, Baertsch R, Salama SR, Ellrott K, Chopra M, Goldstein TC, Haussler D, Morozova O, and Stuart JM. 2017. TumorMap: Exploring the Molecular Similarities of Cancer Samples in an Interactive Portal. Cancer Research 77:e111-e114 DOI: 10.1158/0008-5472.CAN-170580 .

Ogino S, Fuchs CS, and Giovannucci E. 2012. How many molecular subtypes? Implications of the unique tumor principle in personalized medicine. Expert Review of Molecular Diagnostics 12:621-628 DOI: 10.1586/Erm.12.46.

Peifer M, Fernandez-Cuesta L, Sos ML, George J, Seidel D, Kasper LH, Plenker D, Leenders F, Sun R, Zander T, Menon R, Koker M, Dahmen I, Muller C, Di Cerbo V, Schildhaus HU, 
750

751

752

753

754

755

756

757

758

759

760

761

762

763

764

765

766

767

768

769

770

771

772

773

774

775

776

777

778

779

780

781

782

783

784

785

786

787

788

789

790

Altmuller J, Baessmann I, Becker C, de Wilde B, Vandesompele J, Bohm D, Ansen S, Gabler F, Wilkening I, Heynck S, Heuckmann JM, Lu X, Carter SL, Cibulskis K, Banerji S, Getz G, Park KS, Rauh D, Grutter C, Fischer M, Pasqualucci L, Wright G, Wainer Z, Russell P, Petersen I, Chen Y, Stoelben E, Ludwig C, Schnabel P, Hoffmann H, Muley T, Brockmann M, Engel-Riedel W, Muscarella LA, Fazio VM, Groen H, Timens W, Sietsma H, Thunnissen E, Smit E, Heideman DA, Snijders PJ, Cappuzzo F, Ligorio C, Damiani S, Field J, Solberg S, Brustugun OT, Lund-Iversen M, Sanger J, Clement JH, Soltermann A, Moch H, Weder W, Solomon B, Soria JC, Validire P, Besse B, Brambilla E, Brambilla C, Lantuejoul S, Lorimier P, Schneider PM, Hallek M, Pao W, Meyerson M, Sage J, Shendure J, Schneider R, Buttner R, Wolf J, Nurnberg P, Perner S, Heukamp LC, Brindle PK, Haas S, and Thomas RK. 2012. Integrative genome analyses identify key somatic driver mutations of small-cell lung cancer. Nature Genetics 44:1104-1110 DOI: $10.1038 /$ ng. 2396.

Qin AC, and Qian WF. 2018. MicroRNA-7 inhibits colorectal cancer cell proliferation, migration and invasion via TYRO3 and phosphoinositide 3-kinase/protein B kinase/mammalian target of rapamycin pathway suppression. International Journal of Molecular Medicine 42:2503-2514 DOI: 10.3892/ijmm.2018.3864.

Quadri HS, Aiken TJ, Allgaeuer M, Moravec R, Altekruse S, Hussain SP, Miettinen MM, Hewitt SM, and Rudloff U. 2017. Expression of the scaffold connector enhancer of kinase suppressor of Ras 1 (CNKSR1) is correlated with clinical outcome in pancreatic cancer. Bmc Cancer 17: 495 DOI: 10.1186/S12885-017-3481-4.

Ricketts CJ, de Cubas AA, Fan HH, Smith CC, Lang M, Reznik E, Bowlby R, Gibb EA, Akbani R, Beroukhim R, Bottaro DP, Choueiri TK, Gibbs RA, Godwin AK, Haake S, Hakimi AA, Henske EP, Hsieh JJ, Ho TH, Kanchi RS, Krishnan B, Kwaitkowski DJ, Lui WB, Merino MJ, Mills GB, Myers J, Nickerson ML, Reuter VE, Schmidt LS, Shelley CS, Shen H, Shuch B, Signoretti S, Srinivasan R, Tamboli P, Thomas G, Vincent BG, Vocke CD, Wheeler DA, Yang LX, Kim WT, Robertson AG, Spellman PT, Rathmell WK, Linehan WM, and Network CGAR. 2018. The Cancer Genome Atlas Comprehensive Molecular Characterization of Renal Cell Carcinoma. Cell Reports 23:313-326 DOI: 10.1016/j.celrep.2018.03.075.

Ritchie ME, Phipson B, Wu D, Hu Y, Law CW, Shi W, and Smyth GK. 2015. limma powers differential expression analyses for RNA-sequencing and microarray studies. Nucleic Acids Research 43:e47 DOI: 10.1093/nar/gkv007.

Schlicker A, Beran G, Chresta CM, McWalter G, Pritchard A, Weston S, Runswick S, Davenport S, Heathcote K, Castro DA, Orphanides G, French T, and Wessels LF. 2012. Subtypes of primary colorectal tumors correlate with response to targeted treatment in colorectal cell lines. BMC Med Genomics 5:66 DOI: 10.1186/1755-8794-5-66.

Shah MH, Sainger RN, Telang SD, Pancholi GH, Shukla SN, and Patel PS. 2009. E-Cadherin truncation and Sialyl Lewis-X overexpression in oral squamous cell carcinoma and oral precancerous conditions. Neoplasma 56:40-47 DOI: 10.4149/neo_2009_01_40.

Sharma S. 2017. Immunomodulation: A definitive role of microRNA-142. Dev Comp Immunol

Peer) reviewing PDF | (2019:12:43613:2:0:NEW 12 May 2020) 
791

792

793

794

795

796

797

798

799

800

801

802

803

804

805

806

807

808

809

810

811

812

813

814

815

816

817

818

819

820

821

822

823

824

825

826

827

828

829

830

77:150-156 DOI: 10.1016/j.dci.2017.08.001.

Slattery ML, Herrick J, Curtin K, Samowitz W, Wolff RK, Caan BJ, Duggan D, Potter JD, and Peters U. 2010. Increased Risk of Colon Cancer Associated with a Genetic Polymorphism of SMAD7. Cancer Research 70:1479-1485 DOI: 10.1158/00085472.CAN-08-1792.

Song QX, Merajver SD, and Li JZ. 2015a. Cancer classification in the genomic era: five contemporary problems. Human Genomics 9: 27 DOI: 10.1186/s40246-015-0049-8.

Song SM, Honjo S, Jin JK, Chang SS, Scott AW, Chen QR, Kalhor N, Correa AM, Hofstetter WL, Albarracin CT, Wu TT, Johnson RL, Hung MC, and Ajani JA. 2015b. The Hippo Coactivator YAP1 Mediates EGFR Overexpression and Confers Chemoresistance in Esophageal Cancer. Clinical Cancer Research 21:2580-2590 DOI: 10.1158/10780432.CCR-14-2191.

Taherian-Fard A, Srihari S, and Ragan MA. 2015. Breast cancer classification: linking molecular mechanisms to disease prognosis. Briefings in Bioinformatics 16:461-474 DOI: 10.1093/bib/bbu020.

Tan TZ, Rouanne M, Tan KT, Huang RYJ, and Thiery JP. 2019. Molecular Subtypes of Urothelial Bladder Cancer: Results from a Meta-cohort Analysis of 2411 Tumors. European Urology 75:423-432 DOI: 10.1016/j.eururo.2018.08.027.

Teng Y, Ren Y, Hu X, Mu JY, Samykutty A, Zhuang XY, Deng ZB, Kumar A, Zhang LF, Merchant ML, Yan J, Miller DM, and Zhang HG. 2017. MVP-mediated exosomal sorting of miR-193a promotes colon cancer progression. Nature Communications 8: 14448 DOI: 10.1038/Ncomms 14448 .

Tibshirani R, Hastie T, Narasimhan B, and Chu G. 2002. Diagnosis of multiple cancer types by shrunken centroids of gene expression. Proc Natl Acad Sci U S A 99:6567-6572 DOI: 10.1073/pnas.082099299.

Wang B, Mezlini AM, Demir F, Fiume M, Tu ZW, Brudno M, Haibe-Kains B, and Goldenberg A. 2014. Similarity network fusion for aggregating data types on a genomic scale. Nature Methods 11:333-U319 DOI: 10.1038/Nmeth.2810.

Xu T, Le TD, Liu L, Su N, Wang R, Sun B, Colaprico A, Bontempi G, and Li J. 2017. CancerSubtypes: an R/Bioconductor package for molecular cancer subtype identification, validation and visualization. Bioinformatics 33:3131-3133 DOI: 10.1093/bioinformatics/btx378.

Ysebaert L, Chicanne G, Demur C, De Toni F, Prade-Houdellier N, Ruidavets JB, Mansat-De Mas V, Rigal-Huguet F, Laurent G, Payrastre B, Manenti S, and Racaud-Sultan C. 2006. Expression of beta-catenin by acute myeloid leukemia cells predicts enhanced clonogenic capacities and poor prognosis. Leukemia 20:1211-1216 DOI: 10.1038/sj.leu.2404239.

Yu GC, Wang LG, Han YY, and He QY. 2012. clusterProfiler: an R Package for Comparing Biological Themes Among Gene Clusters. Omics-a Journal of Integrative Biology 16:284-287 DOI: 10.1089/omi.2011.0118. 
Figure 1

Cluster labels of single omics clustering.

(A) mRNA. (B) miRNA. (C) CNV. (D) METHY. (E) RPPA. A hypergeometric distribution was used to calculate the P-value for cancer types in each cluster. The rows represent clusters, and the columns represent cancer types. The values represent the -lg(P-value) of cancer types.

Cancer types with $-\lg (P$-value $)>3$ in each cluster were defined as dominant cancer types. All the blank cells mean the instances of P-value $=0$. 
A

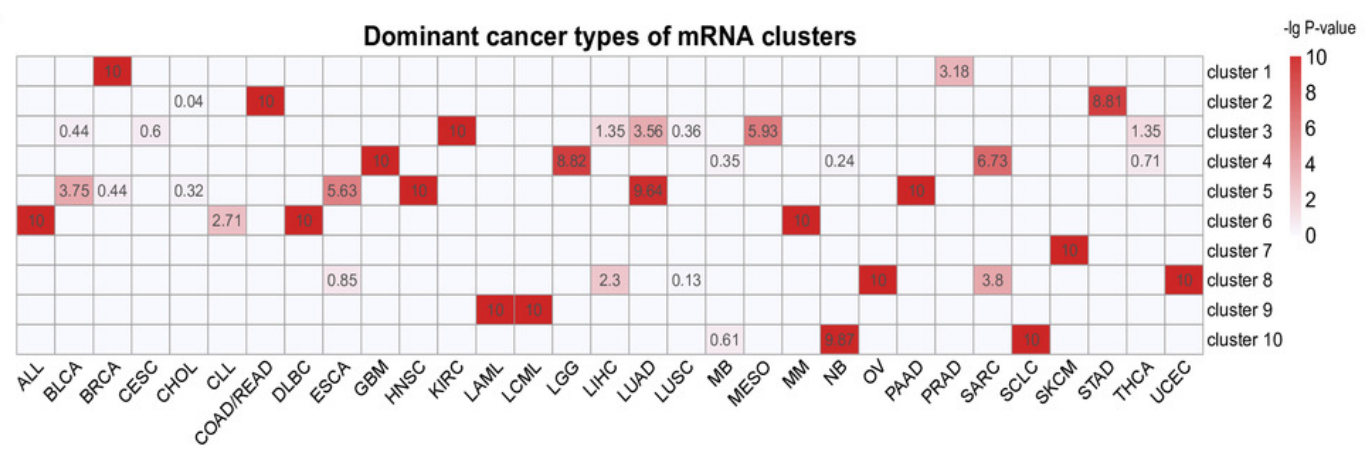

B

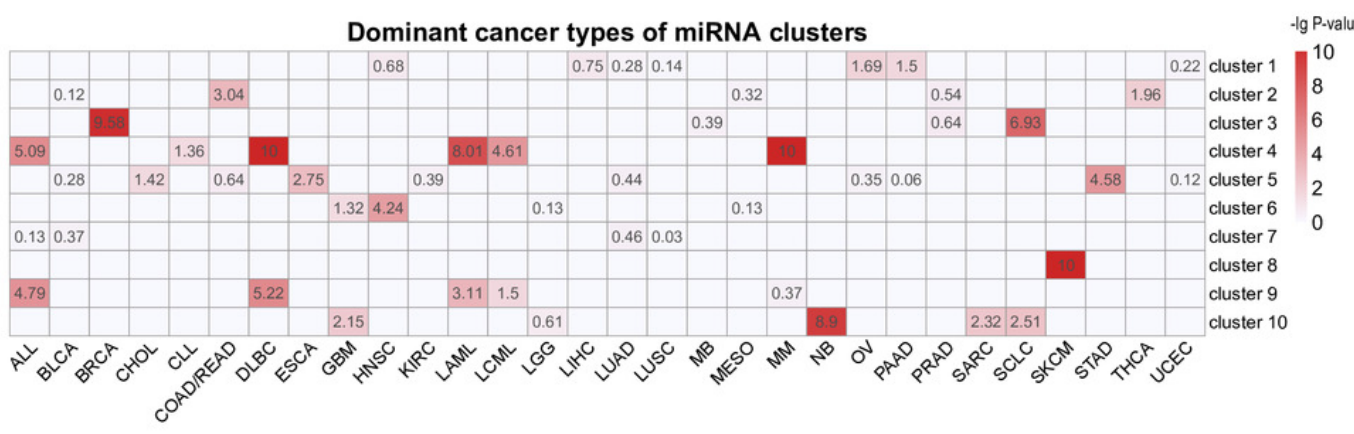

C

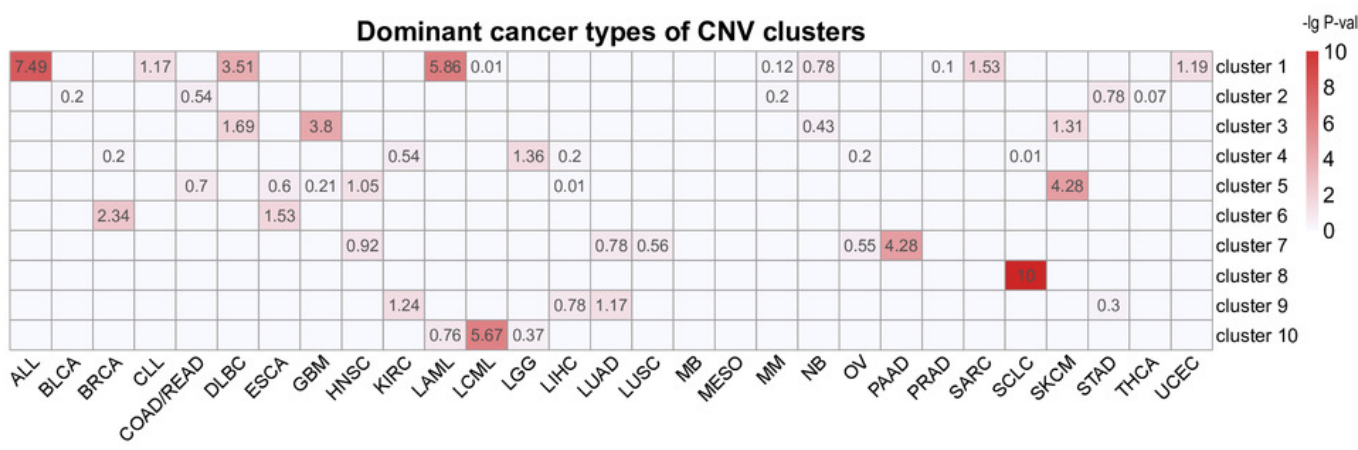

D

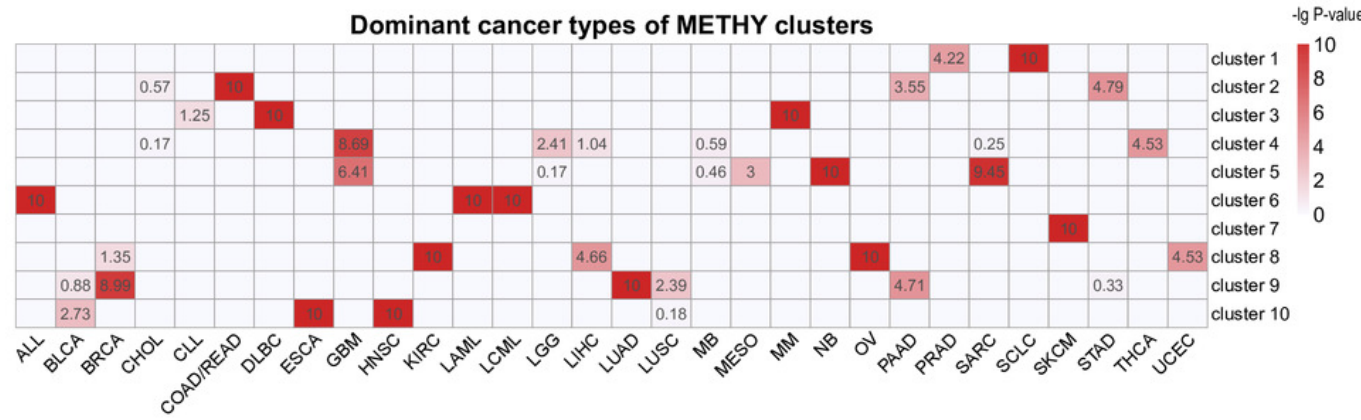

E

Dominant cancer types of RPPA clusters

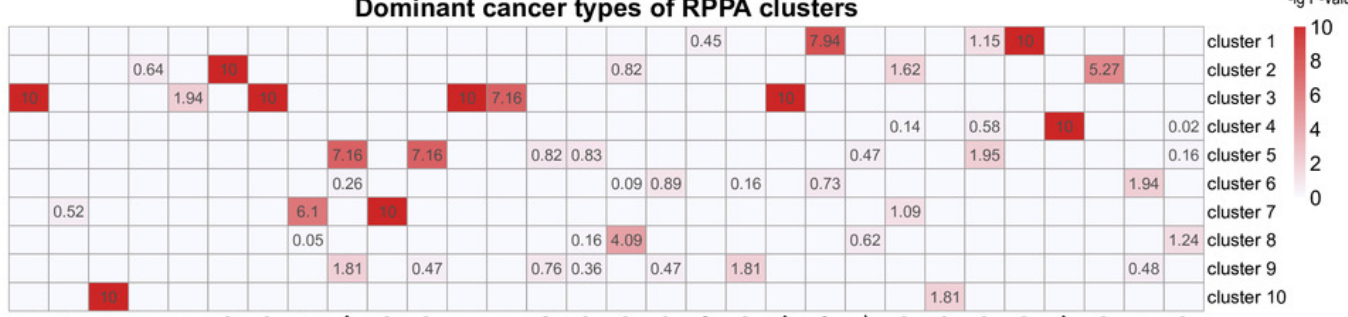

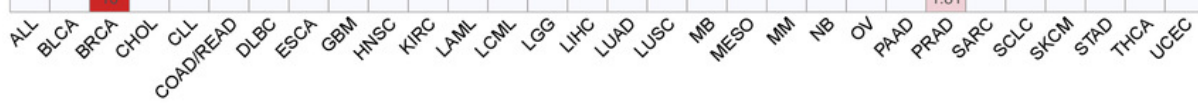




\section{Figure 2}

Classification of pan-cancer cell lines based on integrated multiple omics data.

(A) Data integrated analysis of SNF-CC. Types of cancer cell line are color-coded as shown in the right. The first track represents cell lines of TCGA disease. The second track represents the SNF-CC group. A bar graph was used to show cancer types and the proportion of cell lines in each cluster. The dominant cancer types of each cluster were marked on the top of the bar graph. (B) Clusters composition. Pie charts show the cancer type composition within clusters and the proportion of the membership. The $y$-coordinate of each pie center reflected the dominant cancer types proportion. The $\mathrm{x}$-coordinate was determined by the number of cell lines in each cluster. (C) The contributions of feature (top 20\% NMI) from each omics data. 
$\mathbf{A}$

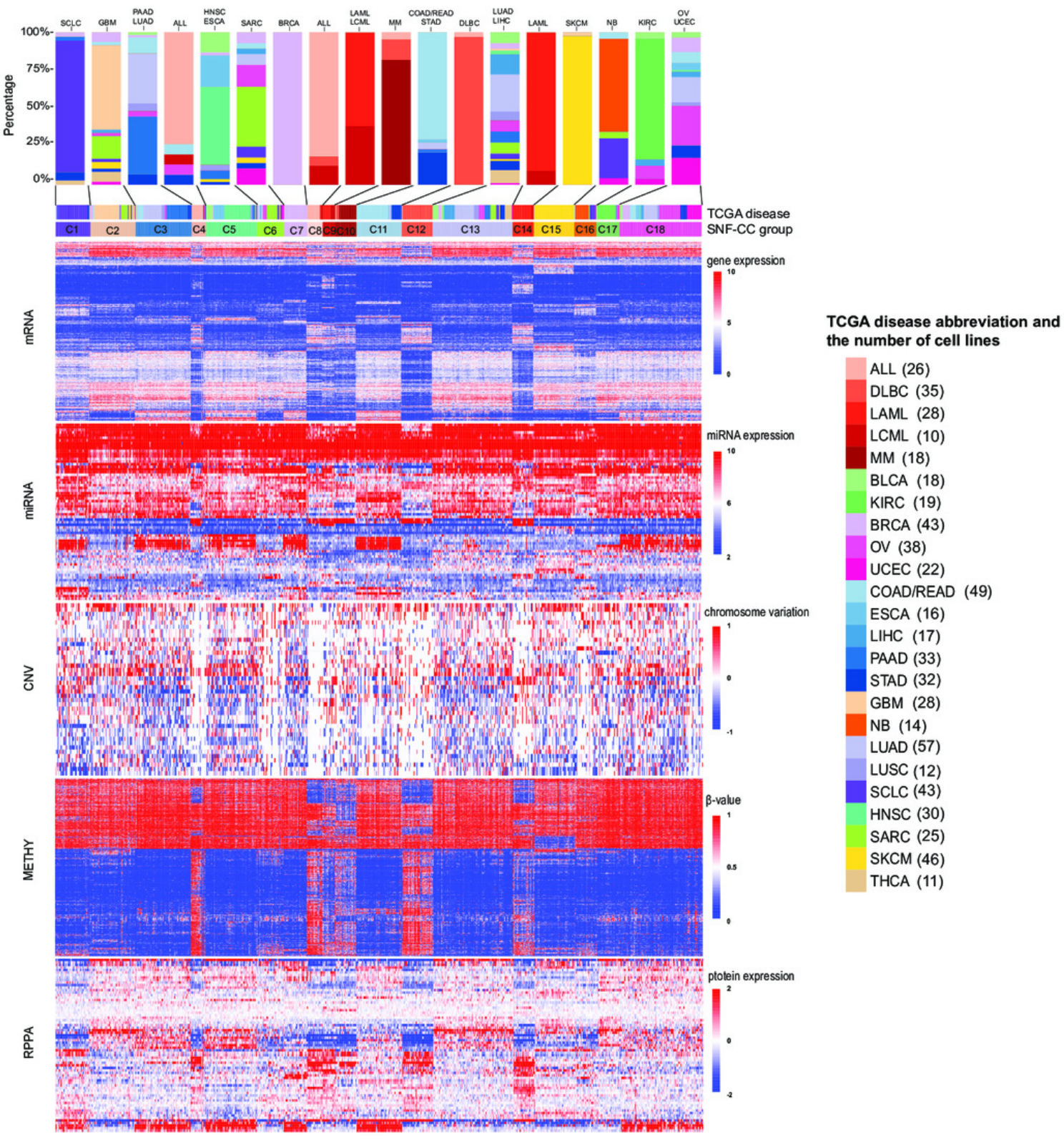

B

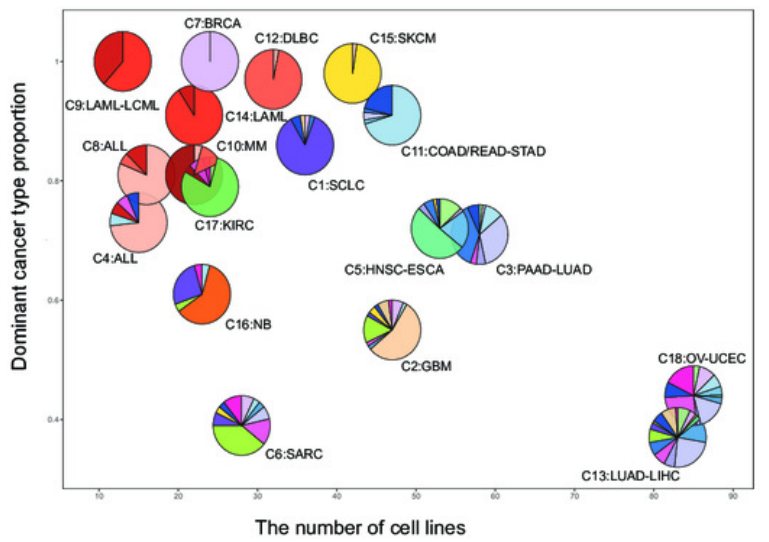

C

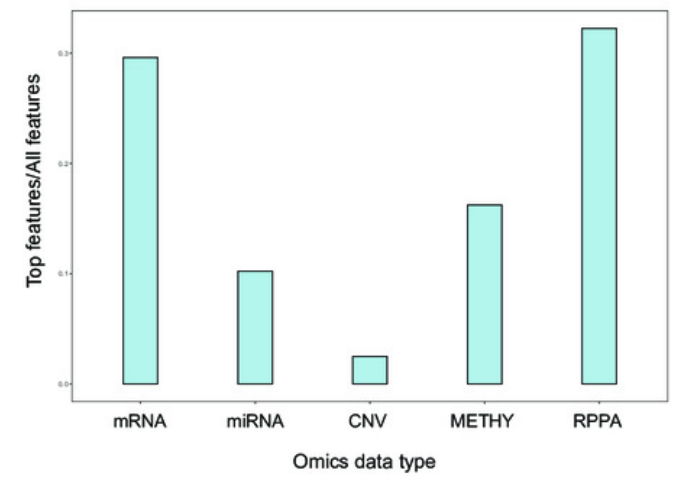




\section{Figure 3}

KEGG and GO enrichment analyses from integrated multiple omics clustering.

(A) KEGG enrichment heatmap of down-regulated genes. (B) KEGG enrichment heatmap of up-regulated genes. (C) GO biological process enrichment heatmap of down-regulated genes. (D) GO biological process enrichment heatmap of up-regulated genes. (E) GO cellular component enrichment heatmap of down-regulated genes. (F) GO cellular component enrichment heatmap of up-regulated genes. (G) GO molecular function enrichment heatmap of down-regulated genes. (H) GO molecular function enrichment heatmap of up-regulated genes. Deeper red color signifies greater enrichment score in all panels. 
A

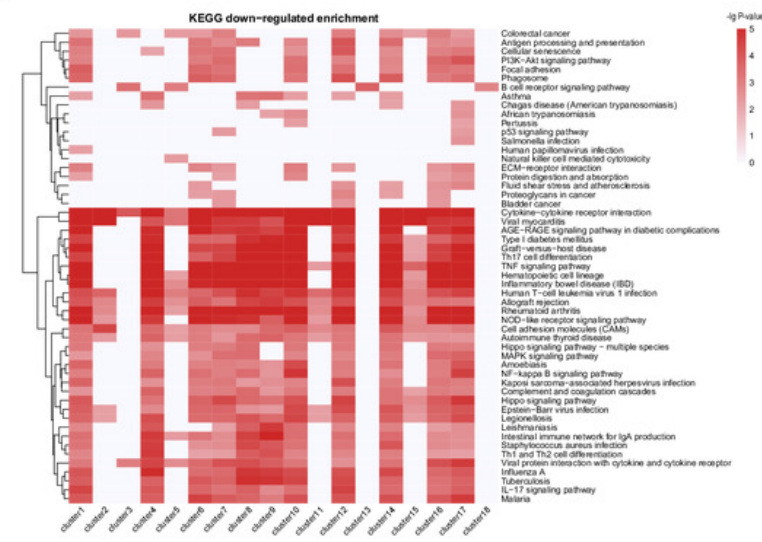

C

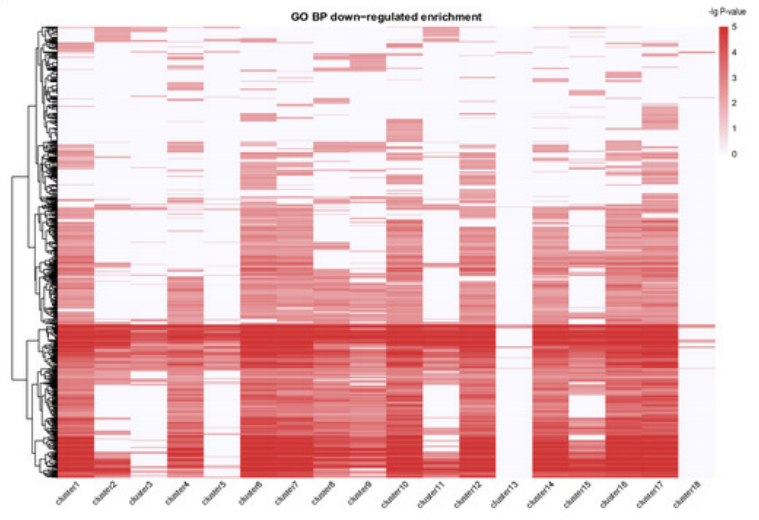

E

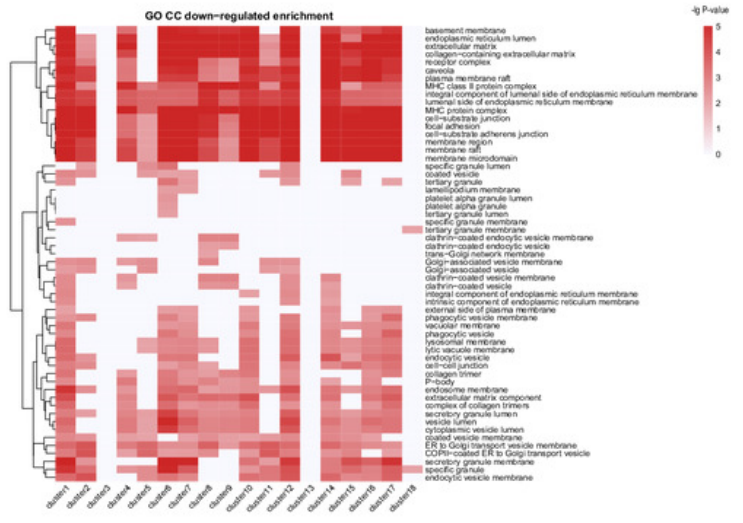

G

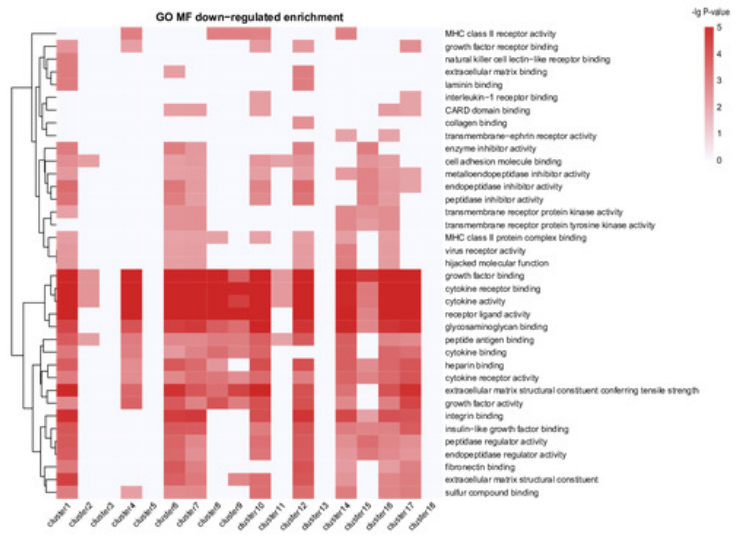

B

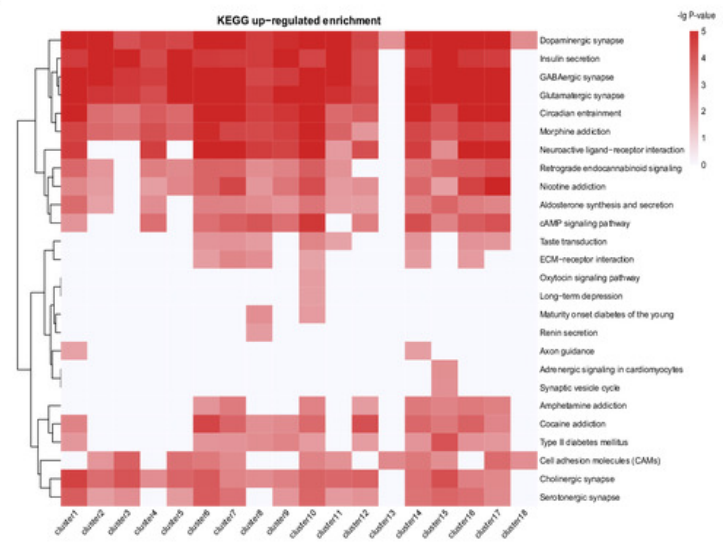

D

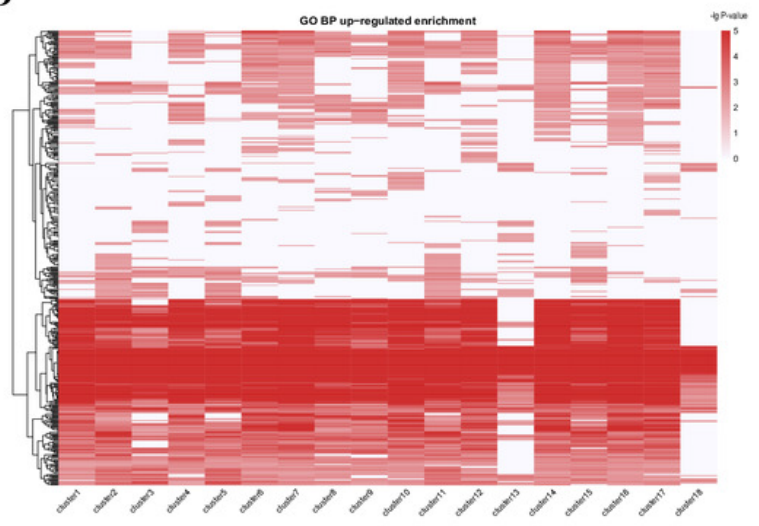

F

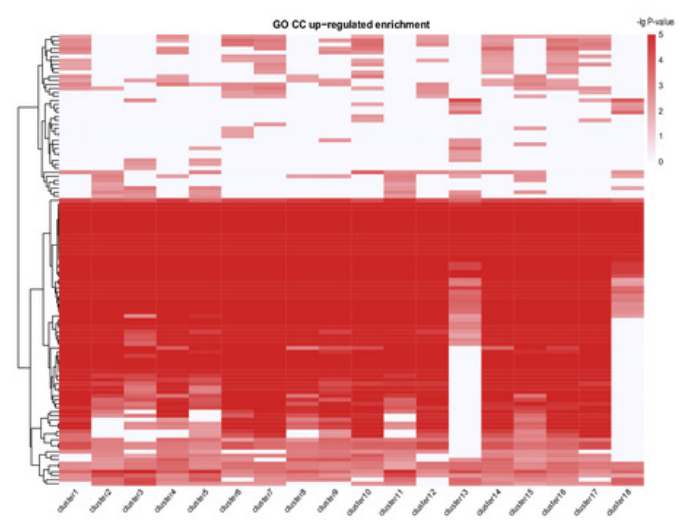

H

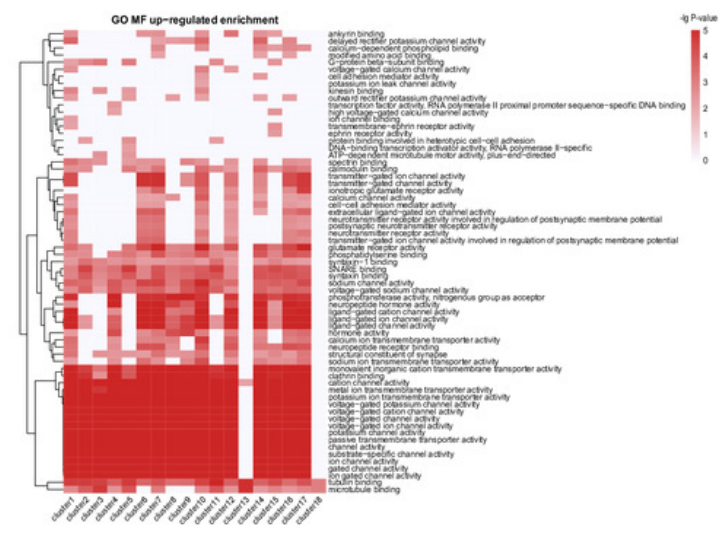


Figure 4

The SNF-CC TumorMap.

The TumorMap layout was computed from cell line Euclidean similarity by NMI features, and similar cell lines were adjacent to each other. Each node represents a single cell line and is colored with attributes including (A) SNF-CC cluster, (B) TCGA disease, (C) Pan organ system and (D) Histology. 
A

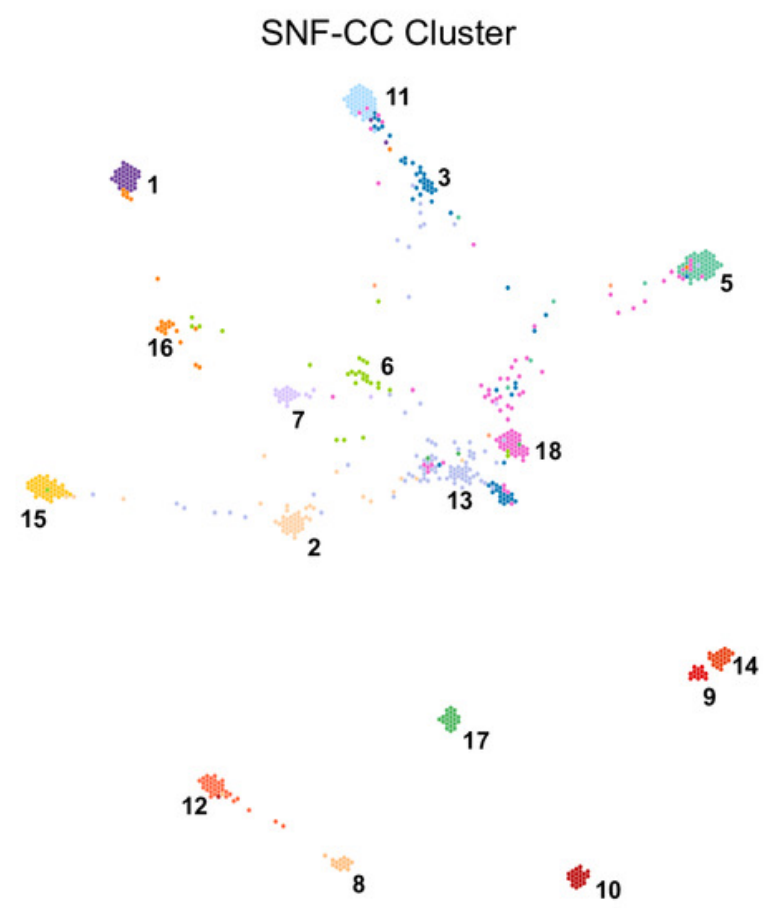

C

Pan Organ System

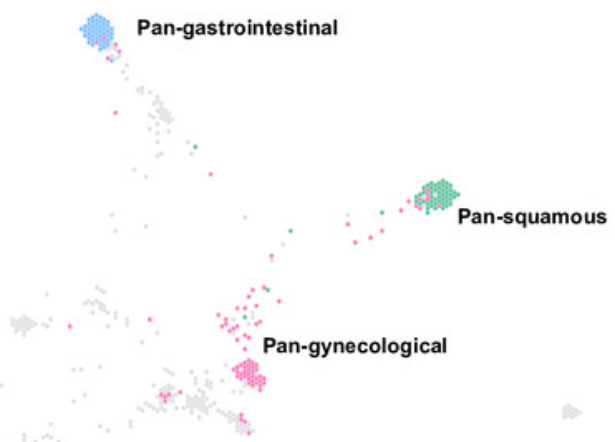

B

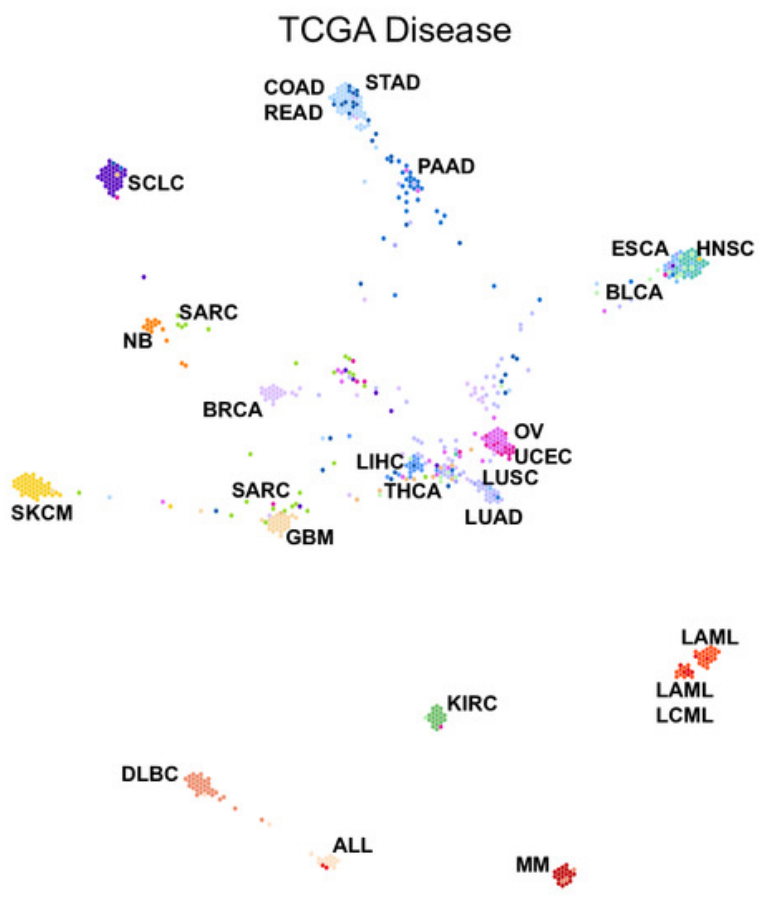

D

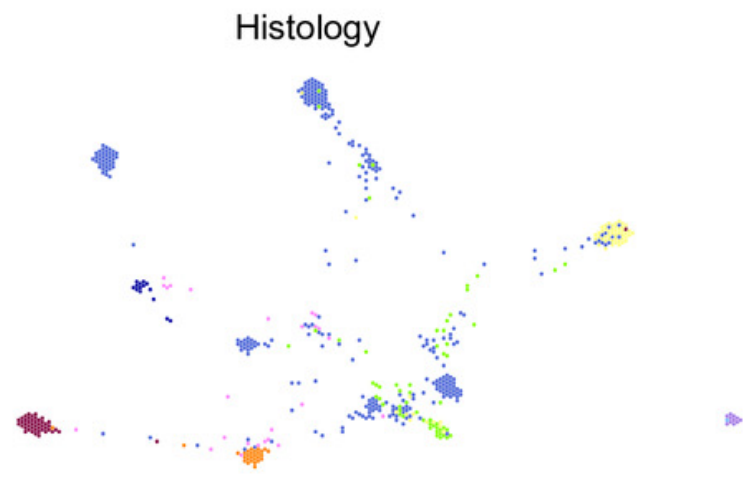




\section{Table $\mathbf{1}$ (on next page)}

The number of cancer cell lines of each type of omics data. 
Table 1:

The number of cancer cell lines of each type of omics data.

\begin{tabular}{|c|c|c|c|c|c|c|c|}
\hline Tumor System & Cancer type & Abbreviation & $\begin{array}{c}\text { Number } \\
\text { of cell } \\
\text { lines of } \\
\text { mRNA } \\
\text { data }\end{array}$ & $\begin{array}{l}\text { Number } \\
\text { of cell } \\
\text { lines of } \\
\text { miRNA } \\
\text { data }\end{array}$ & $\begin{array}{c}\text { Number } \\
\text { of cell } \\
\text { lines of } \\
\mathrm{CNV} \\
\text { data }\end{array}$ & $\begin{array}{c}\text { Number } \\
\text { of cell } \\
\text { lines of } \\
\text { METHY } \\
\text { data }\end{array}$ & $\begin{array}{c}\text { Number } \\
\text { of cell } \\
\text { lines of } \\
\text { RPPA } \\
\text { data }\end{array}$ \\
\hline \multirow{6}{*}{$\begin{array}{l}\text { Hematopoietic } \\
\text { lymphatic } \\
\text { malignancies }\end{array}$} & acute lymphoblastic leukemia & ALL & 31 & 31 & 32 & 30 & 29 \\
\hline & chronic lymphoblastic leukemia & CLL & 4 & 4 & 4 & 2 & 4 \\
\hline & $\begin{array}{l}\text { lymphoid neoplasm diffuse large B- } \\
\text { cell lymphoma }\end{array}$ & DLBC & 39 & 39 & 40 & 37 & 37 \\
\hline & acute myeloid leukemia & LAML & 35 & 31 & 36 & 28 & 31 \\
\hline & chronic myeloid leukemia & LCML & 14 & 14 & 15 & 11 & 13 \\
\hline & multiple myeloma & $\mathrm{MM}$ & 28 & 28 & 30 & 19 & 27 \\
\hline \multirow{4}{*}{$\begin{array}{l}\text { Urologic } \\
\text { system } \\
\text { malignancies }\end{array}$} & bladder urothelial carcinoma & BLCA & 25 & 25 & 23 & 19 & 24 \\
\hline & kidney renal clear cell carcinoma & KIRC & 33 & 23 & 36 & 21 & 21 \\
\hline & prostate adenocarcinoma & PARD & 8 & 7 & 8 & 6 & 7 \\
\hline & breast invasive carcinoma & BRCA & 51 & 50 & 53 & 46 & 47 \\
\hline \multirow{3}{*}{$\begin{array}{l}\text { Gynecologic } \\
\text { cancers }\end{array}$} & $\begin{array}{l}\text { cervical squamous cell carcinoma and } \\
\text { endocervical adenocarcinoma }\end{array}$ & CESC & 2 & 0 & 0 & 0 & 0 \\
\hline & ovarian carcinoma & $\mathrm{OV}$ & 47 & 49 & 49 & 43 & 47 \\
\hline & uterine corpus endometrial carcinoma & UCEC & 28 & 28 & 28 & 22 & 28 \\
\hline \multirow{5}{*}{$\begin{array}{l}\text { Digestive } \\
\text { system tumors }\end{array}$} & cholangiocarcinoma & $\mathrm{CHOL}$ & 8 & 8 & 0 & 7 & 8 \\
\hline & $\begin{array}{l}\text { colon adenocarcinoma/ } \\
\text { rectum adenocarcinoma esophageal } \\
\text { carcinoma }\end{array}$ & $\mathrm{COAD} / \mathrm{READ}$ & 59 & 58 & 57 & 52 & 57 \\
\hline & esophageal carcinoma & ESCA & 27 & 25 & 27 & 17 & 26 \\
\hline & liver hepatocellular carcinoma & LIHC & 25 & 25 & 26 & 19 & 23 \\
\hline & pancreatic adenocarcinoma & PAAD & 41 & 40 & 43 & 35 & 40 \\
\hline
\end{tabular}




\begin{tabular}{|c|c|c|c|c|c|c|c|}
\hline & stomach adenocarcinoma & STAD & 37 & 37 & 38 & 32 & 37 \\
\hline \multirow{4}{*}{$\begin{array}{l}\text { Nervous } \\
\text { system tumors }\end{array}$} & glioblastoma multiforme & GBM & 33 & 33 & 34 & 30 & 34 \\
\hline & brain lower grade glioma & LGG & 10 & 9 & 13 & 6 & 9 \\
\hline & medulloblastoma & MB & 4 & 4 & 4 & 4 & 4 \\
\hline & neuroblastoma & NB & 16 & 16 & 17 & 14 & 16 \\
\hline \multirow{4}{*}{$\begin{array}{l}\text { Thoracic } \\
\text { tumors }\end{array}$} & lung adenocarcinoma & LUAD & 76 & 73 & 70 & 62 & 74 \\
\hline & lung squamous cell carcinoma & LUSC & 26 & 25 & 23 & 15 & 21 \\
\hline & mesothelioma & MESO & 9 & 9 & 9 & 7 & 8 \\
\hline & small cell lung cancer & SCLC & 50 & 50 & 53 & 47 & 45 \\
\hline \multirow{4}{*}{ Others } & $\begin{array}{l}\text { head and neck squamous cell } \\
\text { carcinoma }\end{array}$ & HNSC & 33 & 33 & 32 & 31 & 32 \\
\hline & sarcoma & SARC & 37 & 38 & 31 & 31 & 37 \\
\hline & skin cutaneous melanoma & SKCM & 54 & 55 & 54 & 51 & 55 \\
\hline & thyroid carcinoma & THCA & 11 & 12 & 12 & 11 & 12 \\
\hline
\end{tabular}


Table 2 (on next page)

Methods and measurements for hierarchical clustering. 
1 Table 2:

2 Methods and measurements for hierarchical clustering.

\begin{tabular}{ccc}
\hline Omics data & Method & Distance Measurement \\
\hline mRNA & ward.D & 1-Pearson's correlation coefficient \\
miRNA & ward.D2 & 1-Pearson's correlation coefficient \\
CNV & ward.D2 & Manhattan Distance \\
METHY & ward.D & 1-Pearson's correlation coefficient \\
RPPA & ward.D2 & 1-Pearson's correlation coefficient \\
\hline
\end{tabular}

3 
Table 3 (on next page)

The percentages of the top $20 \% \mathrm{NMI}$ features from each omics data. 
1 Table 3:

2 The percentages of the top $20 \%$ NMI features from each omics data.

\begin{tabular}{cccccc}
\hline & mRNA & miRNA & CNV & METHY & RPPA \\
\hline $\begin{array}{c}\text { The top 20\% NMI } \\
\text { features }\end{array}$ & 5626 & 67 & 1 & 7691 & 69 \\
$\begin{array}{c}\text { All features } \\
\text { Percentage }\end{array}$ & 18,996 & 654 & 40 & 47,362 & 214 \\
\hline
\end{tabular}

3 


\section{Table 4 (on next page)}

The comparison of classification between cancer samples and cell lines. 
1 Table 4:

2 The comparison of classification between cancer samples and cell lines.

\begin{tabular}{|c|c|c|c|c|c|c|}
\hline \multirow[b]{2}{*}{ Cancer types } & \multicolumn{3}{|c|}{ Classification of cancer samples in TCGA } & \multicolumn{3}{|c|}{ Classification of cell lines in CCLE } \\
\hline & $\begin{array}{l}\text { Number of clusters } \\
\text { dominated by } \\
\text { single cancer type }\end{array}$ & $\begin{array}{l}\text { Number of pan- } \\
\text { cancer clusters }\end{array}$ & $\begin{array}{l}\text { Number of clusters } \\
\text { mixed with other } \\
\text { cancer types }\end{array}$ & $\begin{array}{l}\text { Number of clusters } \\
\text { dominated by } \\
\text { single cancer type }\end{array}$ & $\begin{array}{l}\text { Number of pan- } \\
\text { cancer clusters }\end{array}$ & $\begin{array}{l}\text { Number of clusters } \\
\text { mixed with other } \\
\text { cancer types }\end{array}$ \\
\hline$\overline{D L B C}$ & 1 & 0 & 0 & 1 & 0 & 0 \\
\hline LAML & 1 & 0 & 0 & 1 & 0 & 1 \\
\hline BLCA & 0 & 0 & 1 & 0 & 0 & 1 \\
\hline KIRC & 0 & 1 & 0 & 1 & 0 & 0 \\
\hline BRCA & 3 & 0 & 1 & 1 & 0 & 0 \\
\hline $\mathrm{OV}$ & 1 & 0 & 0 & 0 & 1 & 0 \\
\hline UCEC & 1 & 0 & 0 & 0 & 1 & 0 \\
\hline COAD/READ & 0 & 2 & 0 & 0 & 1 & 0 \\
\hline ESCA & 0 & 2 & 0 & 0 & 1 & 0 \\
\hline LIHC & 1 & 0 & 0 & 0 & 0 & 1 \\
\hline PAAD & 0 & 0 & 1 & 0 & 0 & 1 \\
\hline STAD & 1 & 1 & 1 & 0 & 1 & 0 \\
\hline GBM & 0 & 1 & 0 & 1 & 0 & 0 \\
\hline LUAD & 1 & 0 & 0 & 0 & 0 & 2 \\
\hline LUSC & 0 & 1 & 0 & 0 & 0 & 1 \\
\hline HNSC & 0 & 2 & 0 & 0 & 1 & 0 \\
\hline SARC & 0 & 0 & 1 & 1 & 0 & 1 \\
\hline SKCM & 0 & 0 & 1 & 1 & 0 & 0 \\
\hline THCA & 1 & 0 & 0 & 0 & 0 & 1 \\
\hline
\end{tabular}

3 